\title{
The Determinants of Entrepreneurship Gender Gaps: A Cross-Country Analysis
}

\author{
David Cuberes \\ Clark University \\ Sadia Priyanka \\ Clark University \\ Marc Teignier \\ Universitat de Barcelona
}

This version: October 2017

\begin{abstract}
This paper uses aggregate data from the International Labor Organization and microeconomic data from the European Values Study to study the empirical determinants of gender gaps in entrepreneurship, distinguishing between gender gaps in employership and in self-employment. Our sample of 44 countries consists mostly of European countries but varies broadly in terms of income level and institutional background since it includes both Western European countries and former Communist countries. In the aggregate data we observe a gender gap in employers of $67 \%$ and a gender gap in self-employment of $48 \%$. These gaps have slightly decreased in the 2000-2017 period although there are wide differences across countries. The two gaps are very highly correlated but their correlation with per capita GDP is weak. This is an important difference with respect to gender gaps in labor force participation, which tend to follow an inverse U-shape pattern when plotted against income per capita. Using the microeconomic data we find that the incidence of entrepreneurship among men is larger than among women, consistent with the gaps estimated using aggregate data. Our regressions show that these gaps are still sizeable even after controlling for a large set of control variables that include marital status, age, education, number of children, wealth, the participation of parents and spouse in entrepreneurship, values towards women, social capital, and the unemployment rate. Men benefit disproportionately from two of the key determinants in our model, the participation of parents and spouse in entrepreneurship, which have the largest magnitude of influence of selection into that occupation.
\end{abstract}

JEL classification: E2, J21, J24, O40

Keywords: gender gaps, entrepreneurship

\section{Introduction}

Most of the existing empirical work on the determinants of gender gaps in the labor market has focused on gaps in labor force participation. However, as pointed out in Cuberes and Teignier (2016), gender gaps in entrepreneurship are quite large, vary

\footnotetext{
* We thank the Editor for useful guidance on the approach used in the paper.
} 
significantly across countries, and are associated with large output losses at the macroeconomic level.

In this paper we examine the main correlates of gender gaps in entrepreneurship, distinguishing between gaps in employers and self-employed, for a large set of countries. We do so by using data aggregate data from the International Labor Organization (ILO henceforth) and microeconomic data from the European Values Study Survey (EVS henceforth), a microeconomic survey that contains relevant information on different aspects of entrepreneurship and their potential determinants, among many other things.

We use the macro evidence to present differences across countries in these gaps and their evolution over time. However, since it is hard to use macro data to explain these patterns we focus on the microeconomic analysis. Our empirical model using micro data accounts for several factors that affect female entrepreneurship including individual characteristics (family background, education, income, among others) and individual's views on different socioeconomic variables (trust in their society, values towards women, among others). We choose these variables to explain gender gaps following the predictions of economic theory and of related empirical studies. We acknowledge the fact that many of these variables are endogenous and that it is a daunting task to find appropriate instrumental variables for them. Therefore, it is important to emphasize that, throughout the paper, our results should be interpreted as correlation but not causation. While this is an obvious drawback of the study, we believe using microeconomic data to explain crosscountry differences in entrepreneurship and some of their main correlates is an important step towards shedding light on understanding why entrepreneurship is a much less common occupation amon women than men.

The rest of the paper is organized as follows. In Section 2 we take a first look at the aggregate data on gender gaps in entrepreneurship in our sample of countries. Section 3 reviews the literature on the determinants of entrepreneurship with special emphasis on papers that analyze differences between men and women. The empirical strategy of the paper is outlined in Section 4 while the micro data we use is described in Section 5. The empirical results of the study are discussed in Section 6. Finally, Section 7 concludes the paper.

\section{A first look at the aggregate data}

As in Cuberes and Teignier (2016), in this section we use labor market data from the ILO (KILM, 2016) to show some stylized facts about gender gaps in entrepreneurship in our sample of countries. We proxy the number of employers with the variable employers, and 
the number of self-employed with the variable own account workers. We then collect data on these two variables by gender and calculate the following gender gaps:

$$
\text { GGEmp }=1-\frac{E m p^{f}}{E^{m} p^{m}}, \text { GGSelf }=1-\frac{\text { Self }^{f}}{\text { Self }^{m}}
$$

where Emp is the number of employers, Self is the number of self-employed and the superscripts $f$ and $m$ denote females and males, respectively. Naturally, in both cases, if the number of females and males in a given occupation is the same, the gender gap is zero and if there are no women in a given occupation, the gap is equal to one.

We begin by calculating the average gender gaps in employership and self-employment in our pooled data for our sample of 41 countries during the period 2000-2017. ${ }^{1,2}$ Table 1 shows that, on average, for every hundred male employers, there are only 33 female employers. The gap is much lower when one considers self-employment, where there are 52 self-employed women for every hundred self-employed men. In the pooled data, gaps in employership oscillate between $64 \%$ and $69 \%$, whereas those in self-employment display a minimum of $46 \%$ and a maximum of $50 \%$.

Table 1: Summary statistics (in percentages)

\begin{tabular}{ccccc}
\hline & Mean & $\begin{array}{c}\text { Standard } \\
\text { deviation }\end{array}$ & Minimum & Maximum \\
\hline $\begin{array}{c}\text { Gaps in } \\
\text { employership }\end{array}$ & 66.7 & 1.5 & 64.5 & 69.5 \\
\hline $\begin{array}{l}\text { Gaps in self- } \\
\text { employment }\end{array}$ & 47.8 & 1.18 & 46.3 & 49.9 \\
\hline
\end{tabular}

Figure 1 shows that both gaps have been quite constant over time, with the gender gap in employership being about twenty percentage points higher than the one in selfemployment in all years.

Figure 1: Evolution of gender gaps over time

\footnotetext{
${ }^{1}$ The countries are Albania, Armenia, Austria, Belarus, Belgium, Bosnia Herzegovina, Bulgaria, Croatia, Cyprus, Czech Republic, Denmark, Estonia, Finland, France, Georgia, Germany, Greece, Hungary, Iceland, Ireland, Italy, Latvia, Lithuania, Luxembourg, Macedonia, Malta, Montenegro, Netherlands, Norway, Poland, Portugal, Romania, Russian Federation, Serbia, Slovakia, Slovenia, Spain, Sweden, Switzerland, Turkey, and Ukraine.

${ }^{2}$ Northern Ireland is included in the EVS but we omit it here since it is not a country.
} 


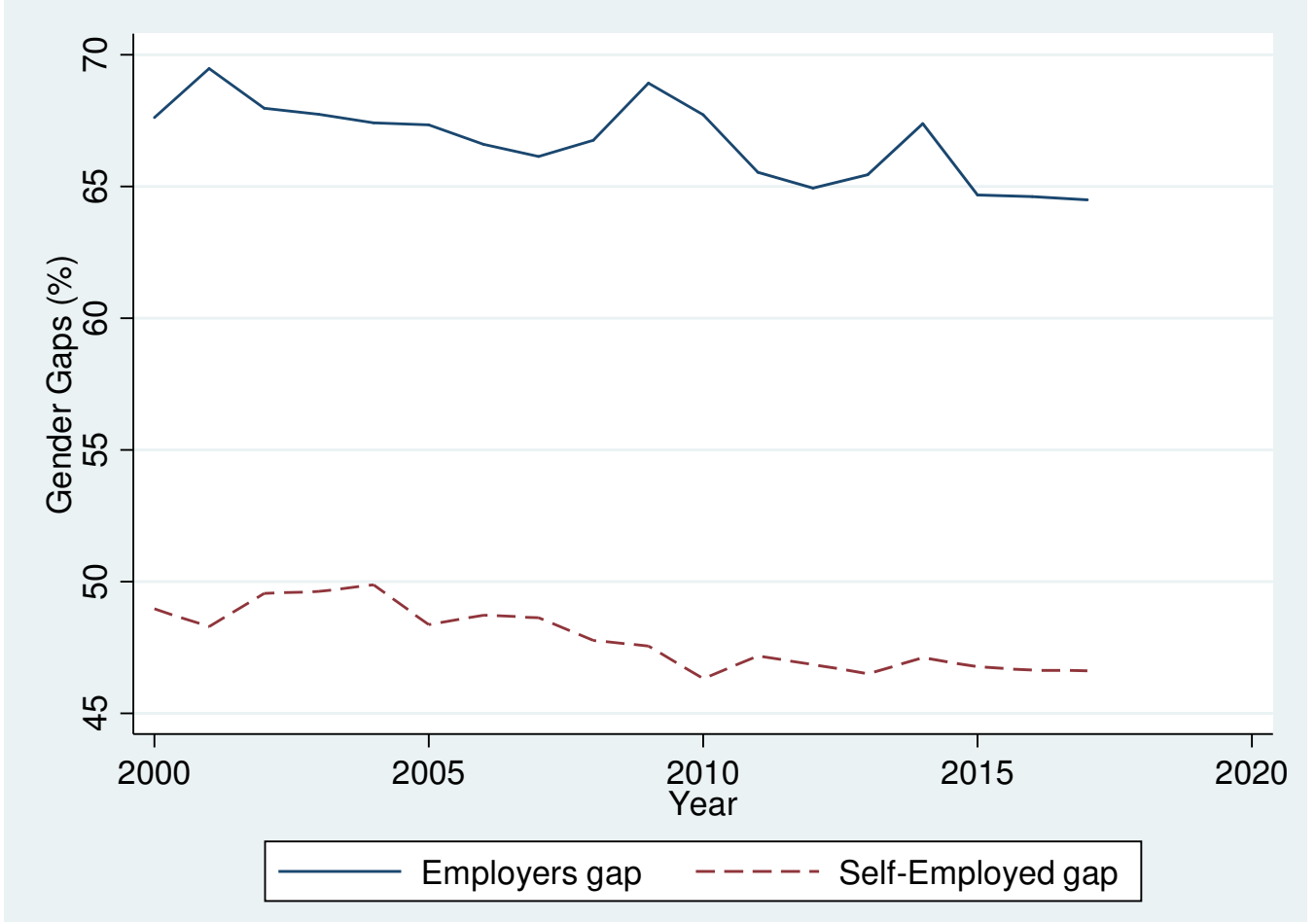

However, as can be seen in Table 1A in the Appendix, both the average gaps and their evolution over time in the 2000-2017 period hide important differences across countries. The country with the largest employers gap is Turkey (93\%), followed by Malta ( $86 \%$ ). On the other hand, Ukraine has a gap of $26 \%$ and it is followed by Russia with a gap of only $46 \%$. Interestingly, the two gaps are highly correlated (0.65), as Figure 2 shows. For instance, the two countries with the largest self-employment gaps are still Turkey (82\%) and Malta (80\%) and Ukraine (-11\%) and Russia (12\%) still have the lowest gaps.

Figure 2: Gender gaps in 2014 


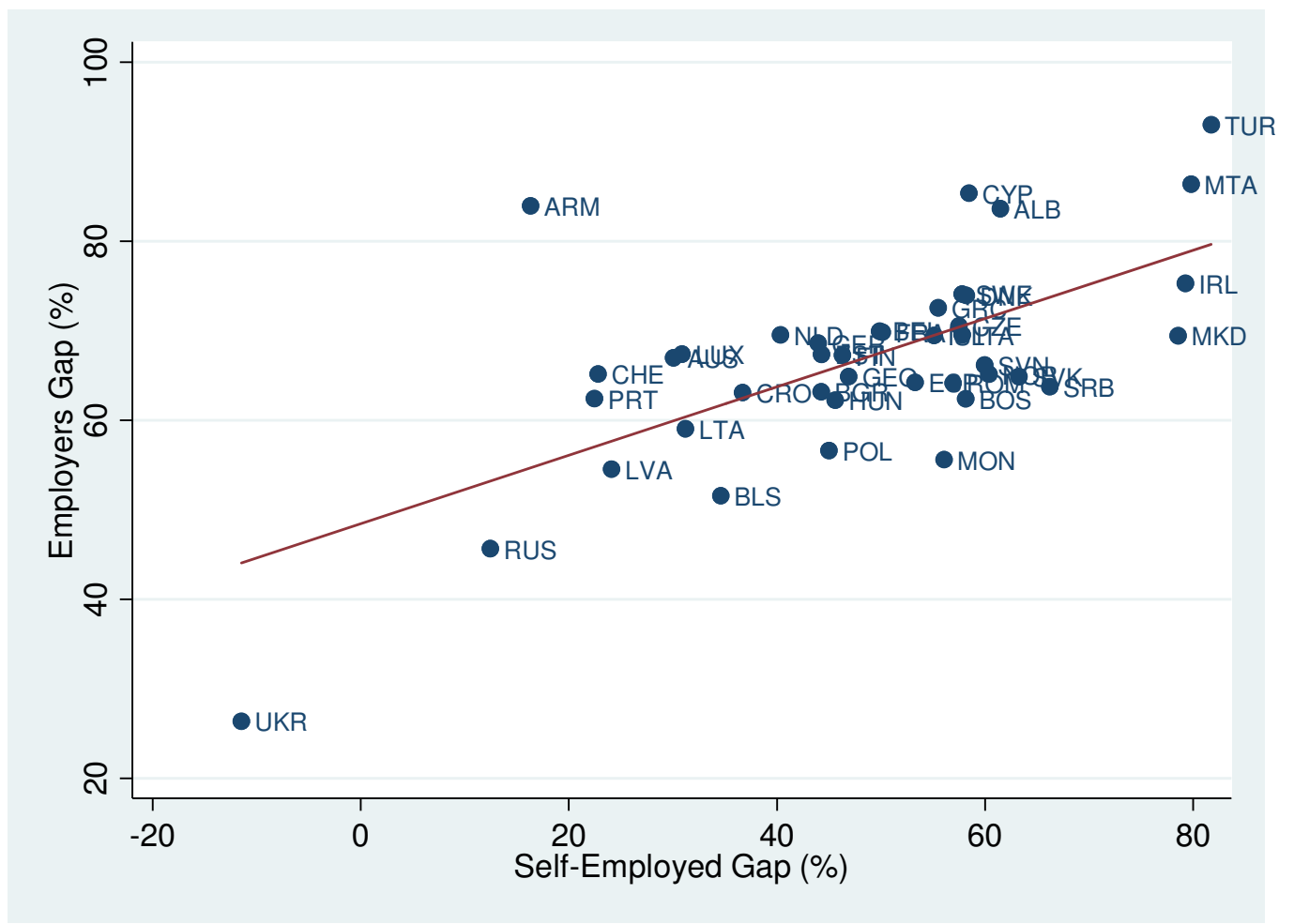

In the Appendix we plot the evolution of these countries over time and, again, there are important differences in the patterns. The gender gap in employership has a clear decreasing pattern in countries like Bosnia and Herzegovina, Georgia, Greece, Ireland, Macedonia, Serbia and Spain. On the other hand, Estonia, Montenegro, Norway or Ukraine displays an increase in this gender gap. Gender gaps in self-employment have markedly dropped in Cyprus, the Czech Republic, Denmark, France, Germany, Greece, Hungary, Iceland, Ireland, Italy, Malta, Norway, Slovakia, Spain, Sweden, Switzerland, and Turkey and they present an increasing pattern in Montenegro, Poland, Portugal, Romania, the Russian Federation, and Ukraine.

One natural question to ask is to what extent these gaps correlate with a country's level of development. After all, economic theory (Becker and Lewis, 1973) tells us that gender gaps in female labor force participation tend to fall as countries become richer and this prediction has been confirmed in a number of studies. ${ }^{3}$ Gender gaps in entrepreneurship (either employers or self-employed) may well behave differently, but it is worth exploring how they correlate with economic development. Figure 3 does so by presenting a scatter plot of gender gaps in employers and self-employed with country's real GDP per capita in $2014 .^{4}$ The correlation between these two variables is 0.18 but it is not

\footnotetext{
${ }^{3}$ See Cuberes and Teignier (2014) for a recent review of this literature.

${ }^{4}$ We choose 2014 since it is the most recent year with data on all the countries from the EVS dataset and on GDP per capita from the Penn World Table.
} 
significant at conventional levels. The correlation in the case of self-employment is -0.12 , but it is again not statistically significant.

Figure 3: Gender gaps and GDP per capita in the full sample
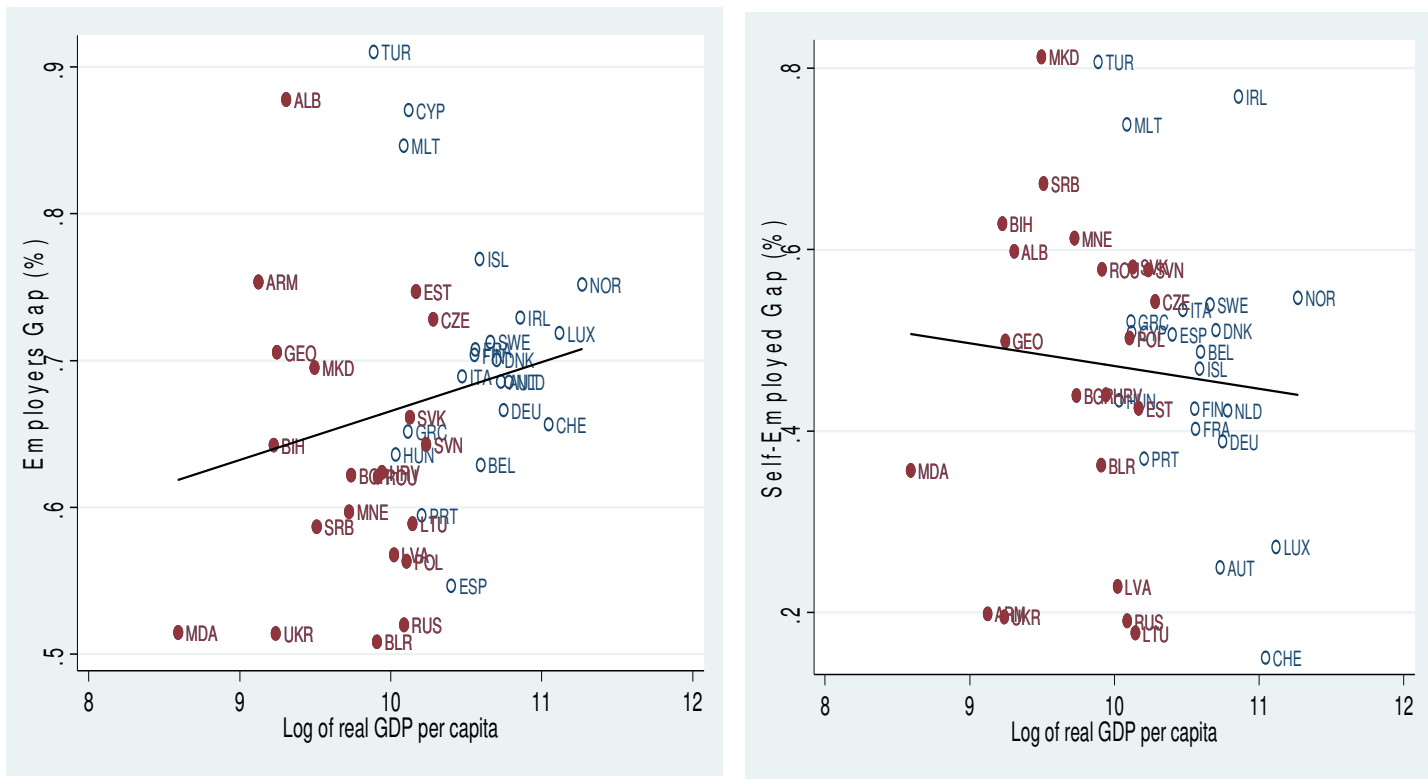

Next we split our sample between "lower income" countries and the rest to check if these patterns vary in any important way. To do that we use as a threshold for "low-income" countries the $25 \%$ of the sample's GDP per capita. ${ }^{5}$ Figure 4 shows that the correlations for, whereas for lower-income countries are 0.38 for employers and 0.57 for selfemployed. One possible interpretation of this finding is that women in lower-income countries tend to become self-employed out of necessity. ${ }^{6}$ However, more research is needed to assert what the motivations of women who choose these occupations in the two groups of countries are.

Figure 4: Gender gaps and GDP per capita in lower-income countries

\footnotetext{
${ }^{5}$ According to this criterion, the sample of low-income countries consists of Albania, Armenia, Bosnia and Herzegovina, Bulgaria, Georgia, Macedonia, Montenegro, Serbia, Turkey, and Ukraine. Moldova should be in this group but we drop it since we don't have information on its GDP in 2014.

${ }^{6}$ On out-of-necessity self-employment, see, for instance, Poschke (2013). The short literature on this topic mostly refers to entrepreneurs in developing countries. Since our sample of countries contains only high and medium income countries perhaps a more appropriate term would be "out-of-choice" self-employed.
} 

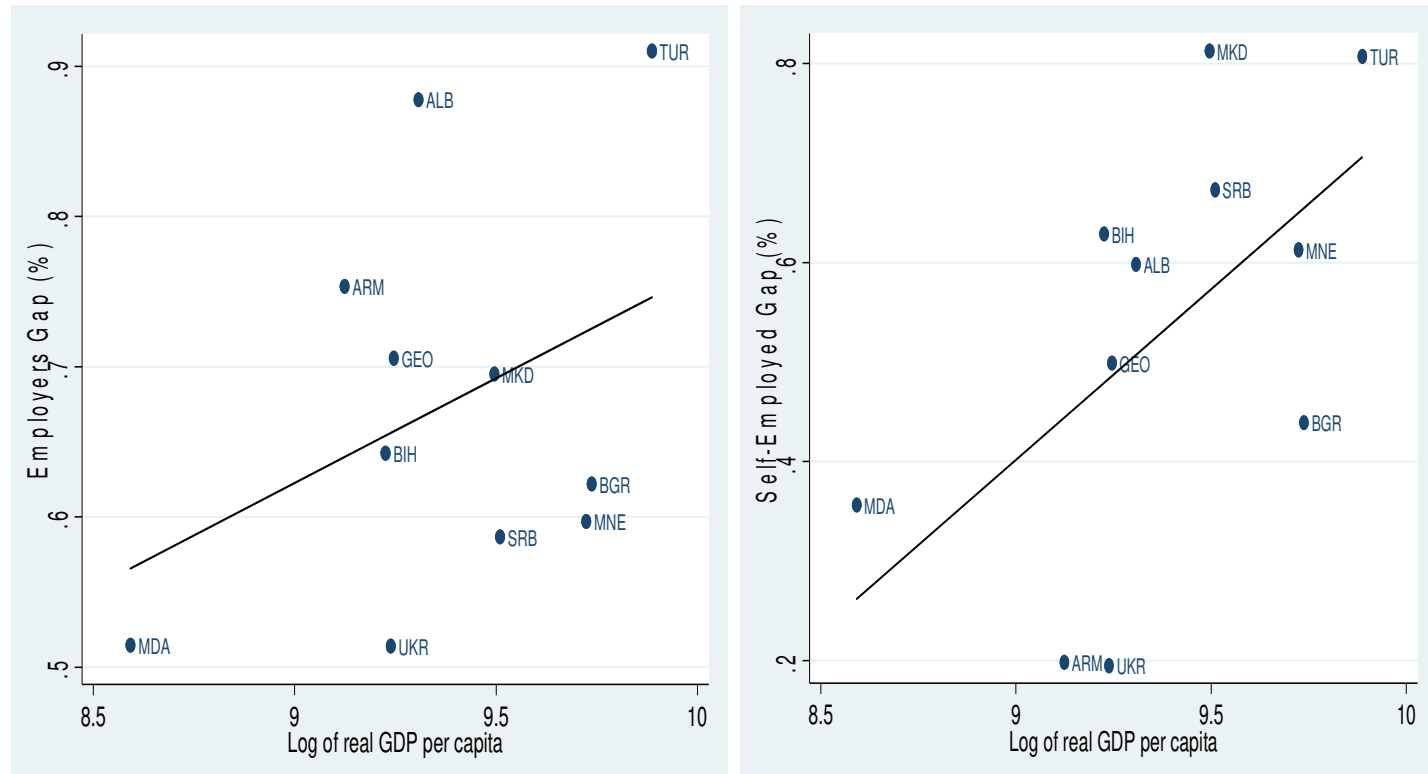

In Figure 3 we highlighted in red full circles Ex-Communist countries. ${ }^{7}$ We do so for three reasons: first, the average level of development in these countries, as measured by their GDP per capita $(18,214)$ is significantly below that of the rest of countries in our sample $(41,331)$. Second, most of these countries belonged to the Soviet bloc for a long period of time and so it seems reasonable to assume that some of their institutions are still significantly different than those of the rest of countries in our sample. We hypothesize that some of these institutions may still affect the role of women in the labor market. Third, values towards women in these countries are typically lower than in the rest of the sample. For example, using data from the World Values Survey ${ }^{8}$, we find that on a scale 1 to 3 (with 1 representing agreement with the statement and 3 representing disagreement with the statement), citizens of Ex-Communist countries significantly agree more on statements like "If jobs are scarce, men should have more right to work than women." or "Men make better business executives than women." For this subsample the relationship between the two gaps and GDP per capita is close to zero

The main goal of our paper is to explain cross-country differences in entrepreneurship gender gaps. However, in results not shown here, we show that, attempting to do so using country-level aggregate data is not very informative. The reason is that, both in the time series and in the cross-section, very few aggregate variables seem to correlate with these gaps. This may be in part due to the fact that our sample of countries is not large enough

\footnotetext{
${ }^{7}$ These include: Albania, Armenia, Belarus, Bosnia and Herzegovina, Bulgaria, Croatia, Czech Republic Estonia, Georgia, Hungary, Latvia, Lithuania, Macedonia, Montenegro, Poland, Romania, Russian Federation, Serbia, Slovakia, Slovenia, and Ukraine.

${ }^{8}$ http://www.worldvaluessurvey.org/wvs.jsp
} 
to estimate regressions with some degree of precision or perhaps due to the fact that to understand entrepreneurship one really needs to use information disaggregated at the individual level. For this reason, we focus on analyzing micro data that dramatically expands our number of observations and allows us to estimate more precisely some of the determinants of cross-country gender differences in entrepreneurship.

\section{Literature}

As mentioned above, the previous literature has analyzed the determinants of gender gaps in labor force participation, leaving gender gaps in entrepreneurship much less explored. Here we summarize this relatively sparse literature and highlight how our study differs from these studies.

Evans and Leighton (1989a) highlight the difficulties in terms of data availability to study the role of small businesses in the economy and they are among the first to use longitudinal data for the US to study several aspects of entrepreneurship. ${ }^{9}$ These type of data has clear advantages since, for example, they allow one to study the determinants of entry and exit into entrepreneurship. ${ }^{10}$ Taylor (1996) uses British data to study the empirical determinants of self-employment and finds that marital status, parents' employment status, housing equity and occupational status are significant determinants of labor market choices. Blanchflower (2000) uses panel data for OECD countries to explore the determinants of self-employment in the 1966-2000 period. ${ }^{12}$ Our study analyzes a more recent cross-section than these papers and, more importantly, it focuses on explaining female entrepreneurship.

Next we focus on papers that have used specific variables to explain entrepreneurship and, in some cases, the interaction of gender with these variables. Instead of summarizing the existing literature in a chronological order, we think it is more informative to sort these papers by the variables that they have studied.

\section{Marital status and children}

Becker's (1985) household division of labor and specialization theory implies that marriage can have a negative effect on one of the spouse's labor market outcomes. If the wife is expected to take on a larger share of household and child related responsibilities, her disposable time devoted to market work would be diminished. Under this pattern of specialization, we then expect to observe a negative effect of marriage on a woman's

\footnotetext{
${ }^{9}$ See the papers cited in this study and in Blanchflower (2000) for more complete literature reviews.

${ }^{12}$ Another example of a paper that uses longitudinal data is Carrasco (1999) who studies transitions into and out of self-employment in Spain.
} 
probability of becoming an entrepreneur. Presumably, this effect would be stronger for the likelihood of being an employer than a self-employed, since, arguably, the former is less flexible and requires more time and effort due to its larger scale of operation.

Blanchflower and Oswald (1990) and Bernhardt (1994) provide evidence in support of the view that having a spouse who works a substantial amount of time outside of the household significantly increases the individual's propensity to be self-employed. Married women are likely to be looking for flexibility in employment in search for a better work-life balance and at a scale that is easily manageable (Wellington, 2006). Le (1999) reviews several empirical papers on the determinants of self-employment in Australia, Canada, Netherlands, the UK and the US. The results of their meta-analysis suggest that self-employment is affected by individual abilities, family background, occupational status, liquidity constraints, and ethnic enclaves. One of the findings of this study is that there exists a positive relationship between marital status and the propensity to be self-employed, though this relationship is often insignificant.

\section{Family background and intergenerational entrepreneurship}

There are several mechanisms for intergenerational transmission of entrepreneurship including direct inheritance of family business, access to capital and industry and firm specific human capital in the form of business networks and preference correlation enhanced through role modeling effects. ${ }^{13}$ Dunn and Holtz-Eakin (2000) finds that parental effect on children's entrepreneurship choice is strongest through intergenerational transmission of human capital skills and not via financial channels, that is, through intergenerational access to wealth. Partners' self-employment status can also positively influence the propensity to select into entrepreneurship (Özcan 2011), through positive assortative mating or sharing of financial and human capital skills. Lindquist et al (2015) find that parental entrepreneurship is a strong determinant for an individual becoming an entrepreneur and that it increases a child's probability of becoming an entrepreneur by $60 \%$.

\section{Financial resources and household wealth}

The positive relationship between wealth and entrepreneurship is well established and is often attributed to evidence of liquidity constraints for new business formation (Evans and Leighton, 1989). Evans and Jovanovic (1989) and Hurst and Lusardi (2004) develop

\footnotetext{
${ }^{13}$ Ruef et al (2003) suggests that role models tend to be of the same gender i.e. mothers tend to influence daughters more than sons, whereas fathers tend to have a stronger influence on sons vs. daughters.
} 
theoretical models in which, in the presence of liquidity constraints, an individual's wealth is an important determinant of his/her likelihood of becoming an entrepreneur. ${ }^{14}$

Blanchflower and Oswald (1998) use various micro data sets from Great Britain to study the main factors affecting the decision to become an entrepreneur and, among other things, they find that the probability of self-employment depends positively upon whether the individual ever received an inheritance or gift. Moreover, potential entrepreneurs say that raising capital is their principal obstacle they face.

\section{Entrepreneurial traits}

There is a newer stream of experimental literature that has increasingly focused on psychological, socio-psychological factors and social gender identity norms to explain gender differences in labor market outcomes and earnings (Bertrand, 2011). In terms of psychological factors that systematically vary between men and women, these studies finds evidence of significant differences in risk preferences, attitude towards competition and negotiation. Some traits that are associated with the propensity to become an entrepreneur include the attitude towards risk, the need for achievement and autonomy, and the internal locus of control and over-confidence (Eren and Sula 2012, Croson and Minitti 2012). If we believe men and women differ along these dimensions, we can perhaps expect these to differentially influence selection into entrepreneurship. However, we are not able to explore this in our current study due to data limitations.

\section{Social Capital}

Putnam (1993) defined social capital as "features of social organization, such as trust, norms, and networks that can improve the efficiency of society by facilitating coordinated actions." He identified four key elements of social capital: cooperation, participation, social interaction and trust. Knack and Keefer (1997) suggest that low trust can deter innovation by entrepreneurs if they have to spend time and money to prevent exploitation in economic transactions. However, these studies analysis do not focus on gender issues. ${ }^{15}$

\section{Education}

The role of education in entrepreneurship has been analyzed, among others, by Ucbasaran et al (2008) and Unger et al (2011) and both studies find a weak relationship between

\footnotetext{
${ }^{14}$ See also Black and Strahan (2002) and Cagetti and DeNardi (2006).

${ }^{15}$ Fairlie and Meyer (1996) study how self-employment rates in the US vary significantly across ethnic and racial groups, perhaps a type of social capital, and use this to inform several theories of selfemployment.
} 
these two variables. Blanchflower (2000) shows that the both the least and the most educated individuals have a higher probability of being self-employed. Wellington (2006) finds that more educated, married women are more likely to be self-employed as a strategy to accommodate work-life balance, although this effect disappears in more recent cohorts.

\section{Unemployment}

Blanchflower (2000) finds that, for most countries, there is a negative relationship between the self-employment rate and the unemployment rate. This evidence would go against the existing theories of out-of-necessity self-employment that claim that individuals tend to become self-employed only when there are no other options for them in the labor market.

\section{Methodology}

In this section, we examine microeconomic correlates of entrepreneurship with a focus on examining the factors that differentially affect men and women's choice of entrepreneurial activity. Our strategy is to estimate probit regressions for the outcome variable $Y$ representing entrepreneurship and types of entrepreneurial activity: employership and self-employment for individual $i$ in county $j .{ }^{16}$

$$
p_{i j}=\alpha+\gamma_{j}+\beta^{\prime} X_{i j}+\varepsilon_{i j}
$$

where $p_{i j}$ is the probability that individual $i$ in country $j$ is an employer (or self-employed, depending on the regression), $X_{i j}$ is a vector of explanatory variables that may correlate with this probability, $\gamma_{j}$ is a country fixed-effect and, finally, $\varepsilon_{i j}$ is a standard error term clustered at the country level, which is assumed to follow a normal distribution. Our key variable of interest included in the vector $X$ is female, a dummy variable that takes a value of 1 if the individual is a woman and 0 if he is a man.

When we estimate (1) using the entire sample of observations, the coefficient on gender tells us whether women are more or less likely to become entrepreneurs compared to men. However, this model does not allow us to test how each of the variables in $X$ affects the likelihood of becoming an entrepreneur differently for men and women. To address this, we could interact these regressors with our gender dummy, hence using the entire dataset in the estimation. However, given that the number of observations in our

\footnotetext{
${ }^{16}$ Estimating a logit model gives us qualitatively similar results.
} 
regressions is very large, we prefer to split the sample for men and women and estimate (1) for each subsample.

\section{Data}

We use data from EVS, which contains longitudinal information on individuals for the period 1981-2008 in 44 countries in four waves. In results not shown here we show that, for our purposes, exploiting the time dimension of the data does not offer many useful insights. ${ }^{17}$ Therefore, in all the sections that follow, we restrict ourselves to using the cross-section of the fourth wave, 2008-2010 for 44 countries.

The EVS is one of the most comprehensive research projects on human values in Europe. It is a large-scale, cross-national and longitudinal survey research program on how individuals think about family, work, religion, politics, and society. Repeated every nine years in an increasing number of countries, the survey provides insights into the ideas, beliefs, preferences, attitudes, values, and opinions of citizens all over Europe. The 2008 cross-section has data for 44 countries, with all except Turkey located in Europe. The countries included in the sample are the same as those in Table 1A in the appendix, plus Great Britain, Kosovo, and Moldova, for which we do not have all the aggregate data. ${ }^{18}$ Table $2 \mathrm{~A}$ in the appendix shows the number of individuals for each country both weighted and un-weighted. The weights specified in EVS are post-stratification weights that adjust for socio-structural characteristics such as gender and age in the sample to represent the population distribution. ${ }^{19} \mathrm{We}$ use these weights in all our regressions.

In our sample the proportion of women is slightly higher compared to men at $52 \%$. Our main variable of interest is entrepreneurship, and the data allow us to distinguish between two types of entrepreneurial activity: employership and self-employment. Employership refers to entrepreneurs who have at least one employee working for them whereas selfemployment refers to entrepreneurs who are sole proprietors and have no employees working for them. More specifically, we define an entrepreneur with a dummy variable that equals 1 if a person is an entrepreneur, and 0 if he/she is an employee. Similarly, the employer dummy equals 1 if a person is an entrepreneur who employs at least one employee, and zero 0 if the person is an employee. Finally, self-employment is measured with a dummy variable that equals 1 if a person is a sole proprietor with no employees, and 0 if the person is an employee.

\footnotetext{
${ }^{17}$ These results are available from the authors upon request.

${ }^{18}$ Northern Ireland is also available from the EVS dataset but we drop it since it does not have the status of a country.

${ }^{19}$ Details on weights used available here: https://dbk.gesis.org/dbksearch/sdesc2.asp?no=4800\&db=e\&doi $=10.4232 / 1.12458$
} 
Table 2 tabulates these occupations for men and women. The incidence of men in entrepreneurship (14\%) is significantly larger than that of women $(8 \%)$. For employers the figures are $8 \%$ for men and $4 \%$ for women, and for self-employed the corresponding figures are $11 \%$ for men and $8 \%$ for women. This shows an important result from our paper: in all entrepreneurship categories, men are overrepresented and the role of gender is statistically significant, as shown the p-values of the t-test in the last column.

Table 2: Entrepreneurship by gender

\begin{tabular}{llcc}
\hline & Men & Women & p-value \\
\hline Fraction of & 0.145 & 0.078 & 0.000 \\
entrepreneurs & $(0.352)$ & $(0.268)$ & \\
\hline Fraction of employers & 0.081 & 0.04 & 0.000 \\
& $(0.113)$ & $(0.195)$ & 0.000 \\
\hline Fraction of self- & 0.113 & 0.084 & \\
employed & $(0.316)$ & $(0.277)$ &
\end{tabular}

Table $3 \mathrm{~A}$ in the appendix shows the corresponding fractions of each category of entrepreneurs in each of the 44 countries. The fraction effect of gender on entrepreneurship gap varies significantly among the 44 countries in the sample ${ }^{20}$. The difference in entrepreneurship by men and women varies from a gap of $2 \%$ in Germany and Russia to $15 \%$ in Italy and Turkey. For employership, this gap ranges between $2 \%$ for countries like Belarus, Finland, Hungary, Latvia, Luxembourg, Ukraine to $17 \%$ for Greece. For self-employed individuals the gap is between $1 \%$ in Lithuania and $16 \%$ for Turkey.

Apart from the gender dummy, the vector $X$ includes the following micro variables: age, education, marital status, children, family background, social capital and unemployment. Table 3 lists each of our controls and the proxy we use from the EVS dataset:

Table 3: Variables used in the model and their proxies

\begin{tabular}{|l|l|}
\hline \multicolumn{1}{|c|}{ Variable } & \multicolumn{1}{c|}{ Proxy } \\
\hline Marital status & Dummy variable that equals 1 if married, 0 otherwise \\
\hline Age & Continuous variables that captures age of respondents \\
\hline
\end{tabular}

\footnotetext{
${ }^{20}$ At the individual country level, the gender gap fraction in these occupations is not always statistically significant, in part because sample sizes are often quite small at the country level.
} 


\begin{tabular}{|l|l|}
\hline Education & $\begin{array}{l}\text { We include dummy variables for completion of four levels of education } \\
\text { (university, secondary, vocational and elementary) with elementary level } \\
\text { as the reference group. }\end{array}$ \\
\hline $\begin{array}{l}\text { Number of } \\
\text { children }\end{array}$ & $\begin{array}{l}\text { A continuous variable that captures how many children respondent has } \\
\text { (deceased children not included) }\end{array}$ \\
\hline $\begin{array}{l}\text { Financial } \\
\text { resources and } \\
\text { household wealth }\end{array}$ & $\begin{array}{l}\text { Three dummy variables that indicate whether a household income level is } \\
\text { classified as low, medium or high }{ }^{22} \text { with low income as the reference } \\
\text { group }\end{array}$ \\
\hline $\begin{array}{l}\text { Intergenerational } \\
\text { entrepreneurship }\end{array}$ & $\begin{array}{l}\text { Dummy variable that equals 1 if parent's were entrepreneurs when } \\
\text { respondent was 14 years of age, } 0 \text { if worked as employee }\end{array}$ \\
\hline $\begin{array}{l}\text { Partner } \\
\text { entrepreneur }\end{array}$ & $\begin{array}{l}\text { Dummy variables that equals 1 if partner is an entrepreneur, 0 if partner is } \\
\text { an employee }\end{array}$ \\
\hline $\begin{array}{l}\text { Values towards } \\
\text { women }\end{array}$ & $\begin{array}{l}\text { Respondents are asked whether they agree/disagree with the statement "if } \\
\text { jobs are scarce men should have more right to a job than women." Dummy } \\
\text { variable equals 1 if respondent agrees and } 0 \text { if disagrees. }\end{array}$ \\
\hline Social capital & $\begin{array}{l}\text { Trust in other individuals (=1 if respondent says most people can be } \\
\text { trusted, =0 if respondent says can't be too careful) }\end{array}$ \\
\hline Bnemployment & $\begin{array}{l}\text { Dummy variable for whether the respondent has experienced "any period } \\
\text { of unemployment for longer than } 3 \text { months" }\end{array}$ \\
\hline
\end{tabular}

Table 4 shows descriptive statistics for all the control variables. While overall $54 \%$ of the sample is married, this proportion is higher at $56 \%$ in the sub-sample for men and lower for sub-sample of women at $52 \%$. The average age of women in the sample is slightly higher compared to men by approximately two years. While men and women have similar education attainment at the university and secondary level, a higher proportion of men complete vocational education and women have higher elementary completion rates. The female sub-sample has a $10 \%$ higher proportion of individuals with children. A higher proportion of women are concentrated in low-income households (38\% compared to $30 \%$ for men). Conversely, there are a higher proportion of men in high-income households than women (33\% versus $27 \%$ ). While the fraction of men with parents that are entrepreneurs is similar to that of women, the fraction of women with an entrepreneur partner is twice (15\%) that of women with an entrepreneur partner $(7 \%)$. This is perhaps

\footnotetext{
${ }^{21}$ Vocational education refers to education programs where students go to learn specific trades. Ideally one would like to measure managerial abilities, which are not necessarily related to education. However, it is difficult to find proxies for these abilities, especially to establish comparisons between countries.

${ }^{22}$ Capital gains from housing and inheritances have been used to proxy for household wealth in some models to circumvent potential endogeneity issues but our dataset does not allow us to use these alternative variables.
} 
not surprising given the higher incidence of entrepreneurship among men than among women. Finally, in each sub-sample, women and men on average have similar levels of trust in other people and a similar proportion are unemployed. In the female sub-sample, a lower proportion of individuals belong to professional association ( $2 \%$ less).

Table 4: Descriptive statistics

\begin{tabular}{|c|c|c|c|c|c|c|c|}
\hline \multirow[t]{2}{*}{ Variables } & \multicolumn{3}{|c|}{ Full Sample } & \multicolumn{2}{|c|}{ Male } & \multicolumn{2}{|c|}{ Female } \\
\hline & Mean & Std Dev & $\begin{array}{l}\text { p values } \\
\text { (gender } \\
\text { diff) }\end{array}$ & Mean & Std Dev & Mean & Std Dev \\
\hline Entrepreneur & 0.115 & 0.319 & 0.0000 & 0.145 & 0.352 & 0.078 & 0.268 \\
\hline Employer & 0.062 & 0.242 & 0.0000 & 0.081 & 0.273 & 0.040 & 0.195 \\
\hline Self employed & 0.099 & 0.299 & 0.0000 & 0.113 & 0.316 & 0.084 & 0.277 \\
\hline Female & 0.519 & 0.499 & & & & & \\
\hline Married & 0.540 & 0.498 & 0.0000 & 0.564 & 0.496 & 0.517 & 0.499 \\
\hline Age & 45.70 & 17.74 & 0.0000 & 44.45 & 17.11 & 46.85 & 18.23 \\
\hline University & 0.172 & 0.377 & 0.7891 & 0.174 & 0.379 & 0.171 & 0.376 \\
\hline Secondary & 0.477 & 0.499 & 0.0000 & 0.472 & 0.499 & 0.481 & 0.499 \\
\hline Vocational & 0.180 & 0.384 & 0.0000 & 0.206 & 0.405 & 0.155 & 0.362 \\
\hline Elementary & 0.172 & 0.377 & 0.0000 & 0.149 & 0.356 & 0.194 & 0.395 \\
\hline Children & 0.698 & 0.459 & 0.0000 & 0.647 & 0.478 & 0.745 & 0.436 \\
\hline Low HH Wealth & 0.342 & 0.474 & 0.0000 & 0.296 & 0.457 & 0.384 & 0.486 \\
\hline Mid HH Wealth & 0.358 & 0.479 & 0.0000 & 0.371 & 0.483 & 0.345 & 0.475 \\
\hline High HH Wealth & 0.301 & 0.459 & 0.0000 & 0.333 & 0.471 & 0.271 & 0.444 \\
\hline $\begin{array}{l}\text { Parents } \\
\text { entrepreneur }\end{array}$ & 0.182 & 0.385 & 0.0003 & 0.183 & 0.387 & 0.180 & 0.384 \\
\hline $\begin{array}{l}\text { Partner } \\
\text { entrepreneur }\end{array}$ & 0.115 & 0.319 & 0.000 & 0.073 & 0.261 & 0.146 & 0.353 \\
\hline $\begin{array}{l}\text { Values towards } \\
\text { women }\end{array}$ & 0.258 & 0.438 & 0.0000 & 0.293 & 0.455 & 0.227 & 0.419 \\
\hline Trust in people & 0.303 & 0.460 & 0.0001 & 0.308 & 0.462 & 0.298 & 0.458 \\
\hline Association & 0.049 & 0.215 & 0.0000 & 0.059 & 0.235 & 0.039 & 0.195 \\
\hline Unemployment & 0.261 & 0.439 & 0.0023 & 0.256 & 0.436 & 0.266 & 0.442 \\
\hline
\end{tabular}

\section{Empirical results}

Our strategy is to estimate (1) for different samples. We first analyze the effects of gender on entrepreneurship in the full sample. Next, we estimate the same regression for the subsample of Ex-Communist countries. We focus our attention in these two groups although we also estimate regressions for lower income countries. However, since the 
results for this group are not very different, we do not present them here ${ }^{23}$. For the three samples we estimate regressions splitting the sample of men and women to capture the effects of gender on each regressor. We also estimate pooled regressions in which both men and women are included. However, this is of less interest for us since only the gender dummy identifies the effect of being a man or a woman on entrepreneurship. Again, to save space, a summary of these regressions is relegated to the appendix.

Table 5 shows the results of estimating (1) with the samples of men and women separately. As mentioned above, this has the advantage of allowing us to observe how the effect of each regressor differs by gender. Being married only reduces the incidence of entrepreneurship in men. The effect of age is positive but it is statistically significant only for men, a result that we find interesting since it may suggest that women face more barriers to entrepreneurship than men as they age. Having university-level education reduces the likelihood of men becoming self-employed. Most of the literature finds no effect of education on self-employment so we view this result as somewhat puzzling. One interpretation of this finding is that more educated men tend to engage in larger scale of operations. The number of children now has a positive and significant effect on the incidence of employership among men. Somewhat surprisingly, the effect of wealth is often negative and significant for both men and women and in different entrepreneurship activities. Having parents that are entrepreneurs' increases the incidence of entrepreneurship in all categories for both men and women but the effect is larger in the case of men, except for self-employment. The same is true for the influence of having a partner who is an entrepreneur, which has the largest magnitude of influence on the likelihood of selecting into entrepreneurship in our model. Trust has a positive effect only on men being an entrepreneur and an employer. Finally, unemployment is positively associated with women being self-employed (3\% more likely) which may be interpreted as evidence in favor of out-of-necessity self-employment for women perhaps due to lack of labor market opportunities.

${ }^{23}$ These regressions are available from the authors upon request. 
Table 5: Marginal effects by gender in the full sample- regressions split by gender

\begin{tabular}{|c|c|c|c|c|c|c|}
\hline \multirow[b]{2}{*}{ VARIABLES } & \multicolumn{2}{|c|}{ Entrepreneur } & \multicolumn{2}{|c|}{ Employer } & \multicolumn{2}{|c|}{ Self Employed } \\
\hline & M & $\mathrm{F}$ & $\mathrm{M}$ & $\mathrm{F}$ & M & $\mathrm{F}$ \\
\hline \multirow[t]{2}{*}{ Married } & $-0.0319 *$ & -0.00376 & -0.0144 & -0.0171 & -0.0259 & 0.0196 \\
\hline & $(0.0182)$ & $(0.0134)$ & $(0.0176)$ & $(0.0132)$ & $(0.0169)$ & $(0.0140)$ \\
\hline \multirow[t]{2}{*}{ Age } & $0.00127 * *$ & $2.77 \mathrm{e}-05$ & $0.00108 * *$ & 0.000135 & $0.00176^{* * *}$ & 0.000336 \\
\hline & $(0.000643)$ & $(0.000503)$ & $(0.000529)$ & $(0.000372)$ & $(0.000514)$ & $(0.000511)$ \\
\hline \multirow[t]{2}{*}{ University } & -0.0358 & -0.0187 & -0.0161 & 0.000773 & $-0.0476^{* *}$ & -0.0251 \\
\hline & $(0.0483)$ & $(0.0273)$ & $(0.0349)$ & $(0.0203)$ & $(0.0236)$ & $(0.0246)$ \\
\hline \multirow[t]{2}{*}{ Secondary } & -0.00493 & 0.00517 & 0.000599 & 0.0157 & -0.0262 & -0.00589 \\
\hline & $(0.0452)$ & $(0.0262)$ & $(0.0354)$ & $(0.0194)$ & $(0.0251)$ & $(0.0230)$ \\
\hline \multirow[t]{2}{*}{ Vocational } & -0.0267 & 0.0161 & -0.0264 & -0.00174 & -0.0269 & 0.0132 \\
\hline & $(0.0416)$ & $(0.0302)$ & $(0.0285)$ & $(0.0209)$ & $(0.0234)$ & $(0.0279)$ \\
\hline \multirow[t]{2}{*}{ Children } & 0.0163 & 0.0201 & $0.0223^{*}$ & 0.0150 & -0.0175 & 0.0102 \\
\hline & $(0.0172)$ & $(0.0140)$ & $(0.0132)$ & $(0.0102)$ & $(0.0156)$ & $(0.0123)$ \\
\hline \multirow[t]{2}{*}{ Mid HH Wealth } & $-0.0702 * * *$ & $-0.0370 * *$ & $-0.0376^{* *}$ & -0.00759 & $-0.0505 * * *$ & $-0.0350 * *$ \\
\hline & $(0.0238)$ & $(0.0178)$ & $(0.0161)$ & $(0.0155)$ & $(0.0177)$ & $(0.0154)$ \\
\hline \multirow[t]{2}{*}{ High HH Wealth } & $-0.0635^{* *}$ & -0.0179 & -0.00703 & 0.0146 & $-0.0860 * * *$ & $-0.0341 * *$ \\
\hline & $(0.0291)$ & $(0.0193)$ & $(0.0231)$ & $(0.0153)$ & $(0.0215)$ & $(0.0164)$ \\
\hline \multirow[t]{2}{*}{ Parents entrepreneur } & $0.0662 * * *$ & $0.0294 *$ & $0.0403 * * *$ & $0.0219 *$ & $0.0337 *$ & $0.0422 * *$ \\
\hline & $(0.0217)$ & $(0.0159)$ & $(0.0151)$ & $(0.0131)$ & $(0.0204)$ & $(0.0171)$ \\
\hline \multirow{2}{*}{ Partner entrepreneur } & $0.350 * * *$ & $0.302 * * *$ & $0.201 * * *$ & $0.137 * * *$ & $0.243 * * *$ & $0.253 * * *$ \\
\hline & $(0.0347)$ & $(0.0252)$ & $(0.0370)$ & $(0.0230)$ & $(0.0358)$ & $(0.0244)$ \\
\hline \multirow[t]{2}{*}{ Values towards women } & 0.0116 & 0.00201 & 0.00346 & -0.0119 & -0.00204 & 0.0101 \\
\hline & $(0.0142)$ & $(0.0139)$ & $(0.0114)$ & $(0.00845)$ & $(0.0140)$ & $(0.0142)$ \\
\hline \multirow[t]{2}{*}{ Trust in people } & $0.0256^{*}$ & 0.00616 & $0.0220 *$ & 0.00371 & 0.00597 & 0.000315 \\
\hline & $(0.0155)$ & $(0.0145)$ & $(0.0131)$ & $(0.00898)$ & $(0.0125)$ & $(0.0140)$ \\
\hline \multirow[t]{2}{*}{ Association } & 0.0142 & 0.0195 & 0.0165 & 0.0159 & 0.00256 & 0.00957 \\
\hline & $(0.0227)$ & $(0.0246)$ & $(0.0196)$ & $(0.0183)$ & $(0.0154)$ & $(0.0240)$ \\
\hline \multirow[t]{2}{*}{ Unemployment } & 0.000319 & 0.00592 & 0.00878 & -0.00583 & 0.00366 & $0.0313^{* *}$ \\
\hline & $(0.0227)$ & $(0.0149)$ & $(0.0195)$ & $(0.00935)$ & $(0.0164)$ & $(0.0152)$ \\
\hline Pseudo R square & 0.1715 & 0.2307 & 0.1564 & 0.2046 & 0.1949 & 0.2561 \\
\hline Log Likelihood & -902.8 & -631.9 & -560 & -292.3 & -575 & -480.6 \\
\hline Observations & 2,557 & 2,949 & 2,277 & 2,360 & 2,357 & 2,650 \\
\hline Country FE & YES & YES & YES & YES & YES & YES \\
\hline
\end{tabular}




\section{Ex-Communist Countries ${ }^{24}$}

Table 6 shows the results for the sample of Ex-Communist countries. To help with the interpretation of the results, we only highlight here major differences with respect to the results from using the full sample (Table 5). The effect of university-level education (and in some cases secondary and vocational education too) is now more often significant, although it is not always negative. As mentioned above, our reading of the literature is that there is no clear link between education and entrepreneurship so these results and those using the full sample seem consistent with that. Having children only increases the incidence of self-employment in women, perhaps because in these countries selfemployment jobs are very informal and offer a great degree of flexibility. Interestingly, the positive role of parental entrepreneurship is only limited to women for becoming an entrepreneur and specifically self-employed. The positive association of trust with becoming an entrepreneur is only relevant for men in the sample whereas the negative relationship of belonging in a professional association with self-employment is only relevant for men.

\footnotetext{
${ }^{24}$ Albania, Armenia, Bosnia Herzegovina, Bulgaria, Belarus, Croatia, Czech Republic, Estonia, Georgia, Hungary, Kosovo, Latvia, Lithuania, Macedonia, Moldova, Montenegro, Poland, Romania, Russia, Serbia, Slovakia, Slovenia, Ukraine
} 
Table 6: Marginal Effects of Ex Communist Countries by Gender

\begin{tabular}{|c|c|c|c|c|c|c|}
\hline \multirow[b]{2}{*}{ VARIABLES } & \multicolumn{2}{|c|}{ Entrepreneur } & \multicolumn{2}{|c|}{ Employer } & \multicolumn{2}{|c|}{ Self Employed } \\
\hline & $\mathrm{M}$ & $\mathrm{F}$ & M & $\mathrm{F}$ & M & $\mathrm{F}$ \\
\hline \multirow[t]{2}{*}{ Married } & -0.0402 & -0.00345 & -0.0363 & -0.00572 & -0.0196 & 0.00415 \\
\hline & $(0.0318)$ & $(0.0209)$ & $(0.0322)$ & $(0.0185)$ & $(0.0176)$ & $(0.0203)$ \\
\hline \multirow[t]{2}{*}{ Age } & $0.00176^{*}$ & -0.000514 & 0.000190 & -0.000154 & $0.00227 * * *$ & $3.97 \mathrm{e}-05$ \\
\hline & $(0.00103)$ & $(0.000482)$ & $(0.000755)$ & $(0.000476)$ & $(0.000787)$ & (0.000509) \\
\hline \multirow[t]{2}{*}{ University } & -0.0483 & $-0.0538^{*}$ & 0.0281 & $0.115 * * *$ & $-0.0744 * *$ & $-0.0583 *$ \\
\hline & $(0.0554)$ & $(0.0313)$ & $(0.0465)$ & $(0.0409)$ & $(0.0346)$ & $(0.0300)$ \\
\hline \multirow[t]{2}{*}{ Secondary } & -0.0317 & -0.0299 & 0.0495 & $0.0952 * * *$ & -0.0922 & -0.0179 \\
\hline & $(0.0655)$ & $(0.0358)$ & $(0.0430)$ & $(0.0254)$ & $(0.0568)$ & $(0.0390)$ \\
\hline \multirow[t]{2}{*}{ Vocational } & -0.0381 & -0.0259 & 0.0103 & $0.0959 *$ & -0.0598 & -0.0204 \\
\hline & $(0.0619)$ & $(0.0271)$ & $(0.0484)$ & $(0.0530)$ & $(0.0431)$ & $(0.0288)$ \\
\hline \multirow[t]{2}{*}{ Children } & -0.00371 & 0.0145 & 0.0195 & 0.00198 & -0.0306 & $0.0269 *$ \\
\hline & $(0.0287)$ & $(0.0122)$ & $(0.0179)$ & $(0.0115)$ & $(0.0252)$ & $(0.0140)$ \\
\hline \multirow[t]{2}{*}{ Mid HH Wealth } & $-0.0492 *$ & $-0.0380 *$ & -0.0264 & -0.0214 & -0.0197 & $-0.0295 * *$ \\
\hline & $(0.0274)$ & $(0.0218)$ & $(0.0246)$ & $(0.0205)$ & $(0.0227)$ & $(0.0148)$ \\
\hline \multirow[t]{2}{*}{ High HH Wealth } & -0.0194 & -0.0171 & 0.0301 & -0.00233 & $-0.0408 *$ & -0.0218 \\
\hline & $(0.0319)$ & $(0.0240)$ & $(0.0305)$ & $(0.0218)$ & $(0.0210)$ & $(0.0135)$ \\
\hline \multirow[t]{2}{*}{ Parents entrepreneur } & 0.0781 & $0.0916^{* *}$ & 0.0405 & 0.0405 & 0.0107 & $0.113^{* *}$ \\
\hline & $(0.0744)$ & $(0.0463)$ & $(0.0438)$ & $(0.0285)$ & $(0.0493)$ & $(0.0530)$ \\
\hline \multirow[t]{2}{*}{ Partner entrepreneur } & $0.398 * * *$ & $0.333 * * *$ & $0.185 * * *$ & $0.155^{* * *}$ & $0.276 * * *$ & $0.280 * * *$ \\
\hline & $(0.0444)$ & $(0.0248)$ & $(0.0467)$ & $(0.0286)$ & $(0.0462)$ & $(0.0291)$ \\
\hline \multirow[t]{2}{*}{ Values towards women } & 0.00564 & 0.0142 & -0.00218 & -0.00239 & -0.0113 & 0.0195 \\
\hline & $(0.0154)$ & $(0.0151)$ & $(0.0128)$ & $(0.0104)$ & $(0.0157)$ & $(0.0151)$ \\
\hline \multirow[t]{2}{*}{ Trust in people } & $0.0399 *$ & 0.0167 & 0.0233 & 0.0187 & 0.0150 & -0.00198 \\
\hline & $(0.0240)$ & $(0.0187)$ & $(0.0166)$ & $(0.0139)$ & $(0.0166)$ & $(0.0159)$ \\
\hline \multirow[t]{2}{*}{ Association } & -0.0209 & -0.0160 & 0.0182 & 0.00992 & $-0.0599 * * *$ & -0.0214 \\
\hline & $(0.0329)$ & $(0.0303)$ & $(0.0360)$ & $(0.0255)$ & $(0.0112)$ & $(0.0336)$ \\
\hline \multirow[t]{2}{*}{ Unemployment } & 0.0304 & -0.00239 & 0.0296 & -0.00955 & 0.0237 & 0.0256 \\
\hline & $(0.0286)$ & $(0.0168)$ & $(0.0245)$ & $(0.0105)$ & $(0.0185)$ & $(0.0175)$ \\
\hline Pseudo R square & 0.1747 & 0.2994 & 0.1594 & 0.2545 & 0.1989 & 0.3492 \\
\hline Log Likelihood & -474 & -300.5 & -299 & -147.8 & -273 & -205.5 \\
\hline Observations & 1,326 & 1,698 & 1,209 & 1,313 & 1,175 & 1,480 \\
\hline Country FE & YES & YES & YES & YES & YES & YES \\
\hline
\end{tabular}




\section{Conclusions}

In this paper we use aggregate data and microeconomic data to explore the determinants of gender gaps in entrepreneurship in a large sample of countries, most of them in Europe. We find that these gaps are sizeable and they vary significantly over countries but not much over time during the period 2000-2017. These gaps are robust to the inclusion of many socioeconomic controls in our regressions, including marital status, age, education, number of children, wealth, the influence of intergenerational and partner's entrepreneurship, values towards women, social capital, and the unemployment rate. One particularly interesting and robust finding of our study is that men benefit disproportionately more from intergenerational and partner's entrepreneurship than women. Trying to understand why these and other variables affect these gaps is a fundamental step that would need further research.

Finally, as mentioned in the introduction, our findings should be interpreted as correlation but not causation. In particular, this correlation does not prove the existence of discrimination against women; it does, however suggest that discrimination may be a good candidate to explain why it is difficult for women to participate in the labor market of some countries. 


\section{Appendix}

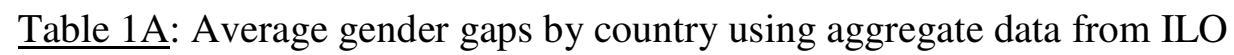

\begin{tabular}{|c|c|c|}
\hline Country & Gender gap in employership & Gender gap in self-employment \\
\hline Albania & 83.6 & 61.4 \\
\hline Armenia & 83.9 & 16.3 \\
\hline Austria & 67 & 30 \\
\hline Belarus & 51.5 & 34.6 \\
\hline Belgium & 70 & 49.9 \\
\hline Bosnia and Herzegovina & 62.4 & 58.1 \\
\hline Bulgaria & 63.2 & 44.2 \\
\hline Croatia & 63.1 & 36.7 \\
\hline Cyprus & 85.3 & 58.4 \\
\hline Czech Republic & 70.5 & 57.5 \\
\hline Denmark & 73.9 & 58.2 \\
\hline Estonia & 67.3 & 44.3 \\
\hline Finland & 67.3 & 46.3 \\
\hline France & 69.8 & 50.1 \\
\hline Georgia & 64.9 & 46.9 \\
\hline Germany & 68.6 & 44 \\
\hline Greece & 72.5 & 55.5 \\
\hline Hungary & 62.2 & 45.6 \\
\hline Iceland & 69.5 & 55.1 \\
\hline Ireland & 75.3 & 79.2 \\
\hline Italy & 69.5 & 57.8 \\
\hline Latvia & 54.5 & 24.1 \\
\hline Lithuania & 59 & 31.2 \\
\hline Luxembourg & 67.4 & 30.9 \\
\hline Macedonia & 69.4 & 78.5 \\
\hline Malta & 86.4 & 79.8 \\
\hline Montenegro & 55.6 & 56 \\
\hline Netherlands & 69.5 & 40.3 \\
\hline Norway & 65.1 & 60.4 \\
\hline Poland & 56.6 & 45 \\
\hline Portugal & 62.4 & 22.5 \\
\hline Romania & 64.1 & 56.9 \\
\hline Russian Federation & 45.7 & 12.5 \\
\hline Serbia & 63.7 & 66.2 \\
\hline Slovakia & 64.9 & 63.2 \\
\hline Slovenia & 66.1 & 59.9 \\
\hline Spain & 64.2 & 53.3 \\
\hline Sweden & 74.1 & 57.8 \\
\hline Switzerland & 65.1 & 22.8 \\
\hline Turkey & 93 & 81.7 \\
\hline Ukraine & 26.4 & -11.5 \\
\hline
\end{tabular}

1.Due to lack of data this does not include Kosovo, Moldova, or Great Britain, which are however included in the microeconomic analysis. Data on gender gaps are not available for Kosovo whereas the ILO only reports data for the United Kingdom, not Great Britain. Finally, while we have data on gender gaps for Moldova, the Penn World Table does not provide a figure for its GDP in 2014 so we drop Moldova from the analysis. 
Table 2A: Country observations un-weighted and weighted

\begin{tabular}{|c|c|c|}
\hline Country & Un-weighted & Weighted \\
\hline Albania & 1534 & 1534.28 \\
\hline Armenia & 1500 & 1477.26 \\
\hline Austria & 1510 & 1510.27 \\
\hline Belarus & 1500 & 1500.27 \\
\hline Belgium & 1509 & 1507.27 \\
\hline Bosnia and Herzegovina & 1512 & 1512.27 \\
\hline Bulgaria & 1500 & 1500.27 \\
\hline Croatia & 1525 & 1498.27 \\
\hline Cyprus & 1000 & 999.18 \\
\hline Czech Republic & 1821 & 1793.32 \\
\hline Denmark & 1507 & 1507.27 \\
\hline Estonia & 1518 & 1518.27 \\
\hline Finland & 1134 & 1134.20 \\
\hline France & 1501 & 1501.27 \\
\hline Georgia & 1500 & 1498.27 \\
\hline Germany & 2075 & 2038.65 \\
\hline Great Britain & 1561 & 1549.28 \\
\hline Greece & 1500 & 1498.27 \\
\hline Hungary & 1513 & 1513.28 \\
\hline Iceland & 808 & 808.15 \\
\hline Ireland & 1013 & 982.18 \\
\hline Italy & 1519 & 1519.27 \\
\hline Kosovo & 1601 & 1601.29 \\
\hline Latvia & 1506 & 1506.27 \\
\hline Lithuania & 1500 & 1499.27 \\
\hline Luxembourg & 1610 & 1609.29 \\
\hline Macedonia & 1500 & 1493.27 \\
\hline Malta & 1500 & 1497.27 \\
\hline Moldova & 1551 & 1551.28 \\
\hline Montenegro & 1516 & 1516.27 \\
\hline Netherlands & 1554 & 1552.28 \\
\hline Norway & 1090 & 1090.20 \\
\hline Poland & 1510 & 1479.27 \\
\hline Portugal & 1553 & 1553.28 \\
\hline Romania & 1489 & 1489.27 \\
\hline Russian Federation & 1504 & 1490.27 \\
\hline Serbia & 1512 & 1512.27 \\
\hline Slovakia & 1509 & 1509.27 \\
\hline Slovenia & 1366 & 1366.25 \\
\hline Spain & 1500 & 1497.27 \\
\hline Sweden & 1187 & 1174.21 \\
\hline Switzerland & 1272 & 1271.23 \\
\hline Turkey & 2384 & 2326.42 \\
\hline Ukraine & 1507 & 1507.27 \\
\hline
\end{tabular}


Table 3A: Entrepreneurship gaps at the country level using micro data (unconditional)

\begin{tabular}{|c|c|c|c|c|c|c|c|c|c|}
\hline \multirow[t]{2}{*}{ Country } & \multicolumn{3}{|c|}{$\begin{array}{c}\text { Fraction of } \\
\text { Entrepreneurs }\end{array}$} & \multicolumn{3}{|c|}{ Fraction of Employers } & \multicolumn{3}{|c|}{ Fraction of self employed } \\
\hline & $\mathrm{M}$ & $\mathrm{F}$ & $\begin{array}{c}\mathrm{p} \\
\text { value }\end{array}$ & M & $\mathrm{F}$ & $\begin{array}{c}\mathrm{p} \\
\text { value }\end{array}$ & M & $\mathrm{F}$ & $\begin{array}{c}\mathrm{p} \\
\text { value }\end{array}$ \\
\hline Albania & $\begin{array}{c}0.43 \\
(0.02)\end{array}$ & $\begin{array}{c}0.38 \\
(0.03)\end{array}$ & 0.0470 & $\begin{array}{c}0.20 \\
(0.02)\end{array}$ & $\begin{array}{c}0.10 \\
(0.02)\end{array}$ & 0.0018 & $\begin{array}{c}0.35 \\
(0.02)\end{array}$ & $\begin{array}{c}0.34 \\
(0.03)\end{array}$ & 0.7383 \\
\hline Armenia & $\begin{array}{c}0.21 \\
(0.02)\end{array}$ & $\begin{array}{c}0.15 \\
(0.02)\end{array}$ & 0.0519 & $\begin{array}{c}0.09 \\
(0.02)\end{array}$ & $\begin{array}{c}0.09 \\
(0.02)\end{array}$ & 0.8636 & $\begin{array}{c}0.20 \\
(0.02)\end{array}$ & $\begin{array}{c}0.15 \\
(0.02)\end{array}$ & 0.1368 \\
\hline Austria & $\begin{array}{c}0.14 \\
(0.02) \\
\end{array}$ & $\begin{array}{c}0.09 \\
(0.01) \\
\end{array}$ & 0.0264 & $\begin{array}{c}0.13 \\
(0.02)\end{array}$ & $\begin{array}{c}0.06 \\
(0.01) \\
\end{array}$ & 0.0015 & $\begin{array}{c}0.10 \\
(0.02) \\
\end{array}$ & $\begin{array}{c}0.09 \\
(0.01)\end{array}$ & 0.7126 \\
\hline Belarus & $\begin{array}{c}0.07 \\
(0.01)\end{array}$ & $\begin{array}{c}0.04 \\
(0.01)\end{array}$ & 0.0465 & $\begin{array}{c}0.04 \\
(0.01)\end{array}$ & $\begin{array}{l}0.016 \\
(0.01)\end{array}$ & 0.0164 & $\begin{array}{c}0.05 \\
(0.01)\end{array}$ & $\begin{array}{c}0.03 \\
(0.01)\end{array}$ & 0.2412 \\
\hline Belgium & $\begin{array}{c}0.08 \\
(0.01) \\
\end{array}$ & $\begin{array}{c}0.06 \\
(0.01) \\
\end{array}$ & 0.2085 & $\begin{array}{c}0.07 \\
(0.01) \\
\end{array}$ & $\begin{array}{c}0.02 \\
(0.01)\end{array}$ & 0.0048 & $\begin{array}{c}0.09 \\
(0.01)\end{array}$ & $\begin{array}{c}0.12 \\
(0.02)\end{array}$ & 0.0543 \\
\hline $\begin{array}{l}\text { Bosnia and } \\
\text { Herzegovina }\end{array}$ & $\begin{array}{c}0.09 \\
(0.02) \\
\end{array}$ & $\begin{array}{c}0.07 \\
(0.02) \\
\end{array}$ & 0.3478 & $\begin{array}{c}0.05 \\
(0.01) \\
\end{array}$ & $\begin{array}{c}0.04 \\
(0.01)\end{array}$ & 0.3754 & $\begin{array}{c}0.06 \\
(0.01)\end{array}$ & $\begin{array}{c}0.05 \\
(0.01)\end{array}$ & 0.7004 \\
\hline Bulgaria & $\begin{array}{c}0.13 \\
(0.02)\end{array}$ & $\begin{array}{c}0.07 \\
(0.01)\end{array}$ & 0.0046 & $\begin{array}{c}0.07 \\
(0.01)\end{array}$ & $\begin{array}{c}0.02 \\
(0.01)\end{array}$ & 0.0041 & $\begin{array}{c}0.08 \\
(0.01)\end{array}$ & $\begin{array}{c}0.06 \\
(0.01)\end{array}$ & 0.2952 \\
\hline Croatia & $\begin{array}{c}0.08 \\
(0.01) \\
\end{array}$ & $\begin{array}{c}0.03 \\
(0.01) \\
\end{array}$ & 0.0026 & $\begin{array}{c}0.06 \\
(0.01)\end{array}$ & $\begin{array}{c}0.02 \\
(0.01) \\
\end{array}$ & 0.0026 & $\begin{array}{c}0.05 \\
(0.01) \\
\end{array}$ & $\begin{array}{c}0.02 \\
(0.01) \\
\end{array}$ & 0.0408 \\
\hline Cyprus & $\begin{array}{c}0.15 \\
(0.02) \\
\end{array}$ & $\begin{array}{c}0.10 \\
(0.02) \\
\end{array}$ & 0.0502 & $\begin{array}{c}0.15 \\
(0.02) \\
\end{array}$ & $\begin{array}{c}0.07 \\
(0.02) \\
\end{array}$ & 0.0070 & $\begin{array}{c}0.16 \\
(0.02) \\
\end{array}$ & $\begin{array}{c}0.16 \\
(0.02) \\
\end{array}$ & 0.9387 \\
\hline $\begin{array}{l}\text { Czech } \\
\text { Republic }\end{array}$ & $\begin{array}{c}0.13 \\
(0.02) \\
\end{array}$ & $\begin{array}{c}0.05 \\
(0.01) \\
\end{array}$ & 0.0000 & $\begin{array}{c}0.05 \\
(0.01) \\
\end{array}$ & $\begin{array}{c}0.01 \\
(0.01) \\
\end{array}$ & 0.0043 & $\begin{array}{c}0.11 \\
(0.01) \\
\end{array}$ & $\begin{array}{c}0.05 \\
(0.01) \\
\end{array}$ & 0.0039 \\
\hline Denmark & $\begin{array}{c}0.14 \\
(0.02)\end{array}$ & $\begin{array}{c}0.04 \\
(0.01) \\
\end{array}$ & 0.0000 & $\begin{array}{c}0.11 \\
(0.01) \\
\end{array}$ & $\begin{array}{c}0.03 \\
(0.01) \\
\end{array}$ & 0.0000 & $\begin{array}{c}0.09 \\
(0.01)\end{array}$ & $\begin{array}{c}0.05 \\
(0.01)\end{array}$ & 0.0060 \\
\hline Estonia & $\begin{array}{c}0.10 \\
(0.01)\end{array}$ & $\begin{array}{c}0.04 \\
(0.01)\end{array}$ & 0.0001 & $\begin{array}{c}0.08 \\
(0.01) \\
\end{array}$ & $\begin{array}{c}0.02 \\
(0.01)\end{array}$ & 0.0000 & $\begin{array}{c}0.05 \\
(0.01)\end{array}$ & $\begin{array}{c}0.03 \\
(0.01)\end{array}$ & 0.0622 \\
\hline Finland & $\begin{array}{c}0.12 \\
(0.02)\end{array}$ & $\begin{array}{c}0.07 \\
(0.01)\end{array}$ & 0.0074 & $\begin{array}{c}0.06 \\
(0.01) \\
\end{array}$ & $\begin{array}{c}0.04 \\
(0.01)\end{array}$ & 0.0974 & $\begin{array}{c}0.11 \\
(0.02)\end{array}$ & $\begin{array}{c}0.06 \\
(0.01)\end{array}$ & 0.0281 \\
\hline France & $\begin{array}{c}0.06 \\
(0.01)\end{array}$ & $\begin{array}{c}0.04 \\
(0.01)\end{array}$ & 0.3517 & $\begin{array}{c}0.07 \\
(0.01)\end{array}$ & $\begin{array}{c}0.04 \\
(0.01)\end{array}$ & 0.0397 & $\begin{array}{c}0.08 \\
(0.01)\end{array}$ & $\begin{array}{c}0.08 \\
(0.01)\end{array}$ & 0.7559 \\
\hline Georgia & $\begin{array}{c}0.27 \\
(0.03)\end{array}$ & $\begin{array}{c}0.16 \\
(0.02)\end{array}$ & 0.0037 & $\begin{array}{c}0.18 \\
(0.03) \\
\end{array}$ & $\begin{array}{c}0.07 \\
(0.02)\end{array}$ & 0.0007 & $\begin{array}{c}0.26 \\
(0.03)\end{array}$ & $\begin{array}{c}0.20 \\
(0.03)\end{array}$ & 0.0636 \\
\hline Germany & $\begin{array}{c}0.08 \\
(0.01)\end{array}$ & $\begin{array}{c}0.06 \\
(0.01) \\
\end{array}$ & 0.0884 & $\begin{array}{c}0.07 \\
(0.01) \\
\end{array}$ & $\begin{array}{c}0.04 \\
(0.01) \\
\end{array}$ & 0.0323 & $\begin{array}{c}0.06 \\
(0.01)\end{array}$ & $\begin{array}{c}0.05 \\
(0.01) \\
\end{array}$ & 0.4297 \\
\hline $\begin{array}{l}\text { Great } \\
\text { Britain }\end{array}$ & $\begin{array}{c}0.18 \\
(0.02) \\
\end{array}$ & $\begin{array}{c}0.08 \\
(0.01) \\
\end{array}$ & 0.0000 & $\begin{array}{c}0.14 \\
(0.02) \\
\end{array}$ & $\begin{array}{c}0.05 \\
(0.01) \\
\end{array}$ & 0.0000 & $\begin{array}{c}0.18 \\
(0.02) \\
\end{array}$ & $\begin{array}{c}0.08 \\
(0.01) \\
\end{array}$ & 0.0001 \\
\hline Greece & $\begin{array}{c}0.35 \\
(0.02)\end{array}$ & $\begin{array}{c}0.25 \\
(0.02) \\
\end{array}$ & 0.0027 & $\begin{array}{c}0.24 \\
(0.02) \\
\end{array}$ & $\begin{array}{c}0.07 \\
(0.02)\end{array}$ & 0.0000 & $\begin{array}{c}0.39 \\
(0.02)\end{array}$ & $\begin{array}{c}0.43 \\
(0.02) \\
\end{array}$ & 0.3140 \\
\hline Hungary & $\begin{array}{c}0.07 \\
(0.01)\end{array}$ & $\begin{array}{c}0.06 \\
(0.01)\end{array}$ & 0.6108 & $\begin{array}{c}0.04 \\
(0.01) \\
\end{array}$ & $\begin{array}{c}0.02 \\
(0.01)\end{array}$ & 0.05 & $\begin{array}{c}0.06 \\
(0.01)\end{array}$ & $\begin{array}{c}0.06 \\
(0.01)\end{array}$ & 0.5413 \\
\hline Iceland & $\begin{array}{c}0.19 \\
(0.02)\end{array}$ & $\begin{array}{c}0.10 \\
(0.02)\end{array}$ & 0.0007 & $\begin{array}{c}0.12 \\
(0.02) \\
\end{array}$ & $\begin{array}{c}0.09 \\
(0.02)\end{array}$ & 0.0910 & $\begin{array}{c}0.14 \\
(0.02)\end{array}$ & $\begin{array}{c}0.07 \\
(0.02)\end{array}$ & 0.0034 \\
\hline Ireland & $\begin{array}{c}0.15 \\
(0.02)\end{array}$ & $\begin{array}{c}0.05 \\
(0.01)\end{array}$ & 0.0000 & $\begin{array}{c}0.08 \\
(0.02)\end{array}$ & $\begin{array}{c}0.02 \\
(0.01)\end{array}$ & 0.0018 & $\begin{array}{c}0.12 \\
(0.02)\end{array}$ & $\begin{array}{c}0.04 \\
(0.01)\end{array}$ & 0.0001 \\
\hline Italy & $\begin{array}{c}0.30 \\
(0.02)\end{array}$ & $\begin{array}{c}0.15 \\
(0.02)\end{array}$ & 0.0000 & $\begin{array}{c}0.21 \\
(0.02)\end{array}$ & $\begin{array}{c}0.10 \\
(0.02)\end{array}$ & 0.0000 & $\begin{array}{c}0.21 \\
(0.02)\end{array}$ & $\begin{array}{c}0.16 \\
(0.02)\end{array}$ & 0.0485 \\
\hline
\end{tabular}




\begin{tabular}{|c|c|c|c|c|c|c|c|c|c|}
\hline Kosovo & $\begin{array}{c}0.31 \\
(0.02)\end{array}$ & $\begin{array}{c}0.17 \\
(0.03)\end{array}$ & 0.0002 & $\begin{array}{c}0.13 \\
(0.02)\end{array}$ & $\begin{array}{c}0.06 \\
(0.02)\end{array}$ & 0.0098 & $\begin{array}{c}0.25 \\
(0.02)\end{array}$ & $\begin{array}{c}0.13 \\
(0.03)\end{array}$ & 0.0007 \\
\hline Latvia & $\begin{array}{c}0.07 \\
(0.01)\end{array}$ & $\begin{array}{c}0.04 \\
(0.01)\end{array}$ & 0.0590 & $\begin{array}{c}0.04 \\
(0.01)\end{array}$ & $\begin{array}{c}0.02 \\
(0.01)\end{array}$ & 0.0119 & $\begin{array}{c}0.04 \\
(0.01)\end{array}$ & $\begin{array}{c}0.03 \\
(0.01)\end{array}$ & 0.1983 \\
\hline Lithuania & $\begin{array}{c}0.12 \\
(0.02)\end{array}$ & $\begin{array}{c}0.04 \\
(0.01)\end{array}$ & 0.0000 & $\begin{array}{c}0.09 \\
(0.01)\end{array}$ & $\begin{array}{c}0.03 \\
(0.01)\end{array}$ & 0.0001 & $\begin{array}{c}0.04 \\
(0.01)\end{array}$ & $\begin{array}{c}0.03 \\
(0.01)\end{array}$ & 0.0950 \\
\hline Luxembourg & $\begin{array}{c}0.05 \\
(0.01) \\
\end{array}$ & $\begin{array}{c}0.05 \\
(0.01) \\
\end{array}$ & 0.6093 & $\begin{array}{c}0.06 \\
(0.01) \\
\end{array}$ & $\begin{array}{c}0.04 \\
(0.01) \\
\end{array}$ & 0.0911 & $\begin{array}{c}0.03 \\
(0.01) \\
\end{array}$ & $\begin{array}{c}0.07 \\
(0.01)\end{array}$ & 0.0009 \\
\hline Macedonia & $\begin{array}{c}0.11 \\
(0.02) \\
\end{array}$ & $\begin{array}{c}0.04 \\
(0.01) \\
\end{array}$ & 0.0013 & $\begin{array}{c}0.06 \\
(0.01) \\
\end{array}$ & $\begin{array}{c}0.03 \\
(0.01) \\
\end{array}$ & 0.0710 & $\begin{array}{c}0.05 \\
(0.01) \\
\end{array}$ & $\begin{array}{c}0.02 \\
(0.01) \\
\end{array}$ & 0.0825 \\
\hline Malta & $\begin{array}{c}0.10 \\
(0.02)\end{array}$ & $\begin{array}{c}0.06 \\
(0.02)\end{array}$ & 0.0370 & $\begin{array}{c}0.08 \\
(0.02)\end{array}$ & $\begin{array}{c}0.04 \\
(0.01)\end{array}$ & 0.0348 & $\begin{array}{c}0.10 \\
(0.02)\end{array}$ & $\begin{array}{c}0.13 \\
(0.02)\end{array}$ & 0.3074 \\
\hline Moldova & $\begin{array}{c}0.17 \\
(0.02)\end{array}$ & $\begin{array}{c}0.08 \\
(0.02)\end{array}$ & 0.0003 & $\begin{array}{c}0.06 \\
(0.02)\end{array}$ & $\begin{array}{c}0.04 \\
(0.01)\end{array}$ & 0.3759 & $\begin{array}{c}0.12 \\
(0.02)\end{array}$ & $\begin{array}{c}0.04 \\
(0.01)\end{array}$ & 0.0003 \\
\hline Montenegro & $\begin{array}{c}0.14 \\
(0.02)\end{array}$ & $\begin{array}{c}0.09 \\
(0.02)\end{array}$ & 0.0170 & $\begin{array}{c}0.06 \\
(0.01)\end{array}$ & $\begin{array}{c}0.05 \\
(0.01)\end{array}$ & 0.6291 & $\begin{array}{c}0.13 \\
(0.02)\end{array}$ & $\begin{array}{c}0.06 \\
(0.01)\end{array}$ & 0.0014 \\
\hline Netherlands & $\begin{array}{c}0.15 \\
(0.02)\end{array}$ & $\begin{array}{c}0.10 \\
(0.01)\end{array}$ & 0.0105 & $\begin{array}{c}0.12 \\
(0.02)\end{array}$ & $\begin{array}{c}0.08 \\
(0.01)\end{array}$ & 0.0170 & $\begin{array}{c}0.12 \\
(0.02)\end{array}$ & $\begin{array}{c}0.13 \\
(0.02)\end{array}$ & 0.6658 \\
\hline Norway & $\begin{array}{c}0.16 \\
(0.02)\end{array}$ & $\begin{array}{c}0.08 \\
(0.01)\end{array}$ & 0.0008 & $\begin{array}{c}0.09 \\
(0.01)\end{array}$ & $\begin{array}{c}0.04 \\
(0.01)\end{array}$ & 0.0069 & $\begin{array}{c}0.13 \\
(0.02)\end{array}$ & $\begin{array}{c}0.07 \\
(0.01)\end{array}$ & 0.0036 \\
\hline Poland & $\begin{array}{c}0.15 \\
(0.02)\end{array}$ & $\begin{array}{c}0.07 \\
(0.01)\end{array}$ & 0.0005 & $\begin{array}{c}0.05 \\
(0.01)\end{array}$ & $\begin{array}{c}0.02 \\
(0.01)\end{array}$ & 0.0118 & $\begin{array}{c}0.03 \\
(0.01)\end{array}$ & $\begin{array}{c}0.02 \\
(0.01)\end{array}$ & 0.2975 \\
\hline Portugal & $\begin{array}{c}0.07 \\
(0.01)\end{array}$ & $\begin{array}{c}0.05 \\
(0.01)\end{array}$ & 0.3896 & $\begin{array}{c}0.06 \\
(0.01)\end{array}$ & $\begin{array}{c}0.03 \\
(0.01)\end{array}$ & 0.0403 & $\begin{array}{c}0.12 \\
(0.02)\end{array}$ & $\begin{array}{c}0.18 \\
(0.02)\end{array}$ & 0.0113 \\
\hline Romania & $\begin{array}{c}0.10 \\
(0.02)\end{array}$ & $\begin{array}{c}0.06 \\
(0.01)\end{array}$ & 0.0320 & $\begin{array}{c}0.03 \\
(0.01)\end{array}$ & $\begin{array}{c}0.03 \\
(0.01)\end{array}$ & 0.9436 & $\begin{array}{c}0.07 \\
(0.01)\end{array}$ & $\begin{array}{c}0.06 \\
(0.01)\end{array}$ & 0.5337 \\
\hline $\begin{array}{l}\text { Russian } \\
\text { Federation }\end{array}$ & $\begin{array}{c}0.04 \\
(0.01) \\
\end{array}$ & $\begin{array}{c}0.02 \\
(0.01) \\
\end{array}$ & 0.0467 & $\begin{array}{c}0.04 \\
(0.01) \\
\end{array}$ & $\begin{array}{c}0.02 \\
(0.01) \\
\end{array}$ & 0.2067 & $\begin{array}{c}0.01 \\
(0.004) \\
\end{array}$ & $\begin{array}{c}0.01 \\
(0.005) \\
\end{array}$ & 0.3515 \\
\hline Serbia & $\begin{array}{c}0.20 \\
(0.02) \\
\end{array}$ & $\begin{array}{c}0.11 \\
(0.02) \\
\end{array}$ & 0.0009 & $\begin{array}{c}0.10 \\
(0.02) \\
\end{array}$ & $\begin{array}{c}0.05 \\
(0.01) \\
\end{array}$ & 0.0171 & $\begin{array}{c}0.16 \\
(0.02) \\
\end{array}$ & $\begin{array}{c}0.10 \\
(0.02) \\
\end{array}$ & 0.0085 \\
\hline Slovakia & $\begin{array}{c}0.13 \\
(0.02) \\
\end{array}$ & $\begin{array}{c}0.07 \\
(0.01) \\
\end{array}$ & 0.0041 & $\begin{array}{c}0.05 \\
(0.01) \\
\end{array}$ & $\begin{array}{c}0.02 \\
(0.01) \\
\end{array}$ & 0.0091 & $\begin{array}{c}0.10 \\
(0.02) \\
\end{array}$ & $\begin{array}{c}0.05 \\
(0.01) \\
\end{array}$ & 0.0129 \\
\hline Slovenia & $\begin{array}{c}0.12 \\
(0.02) \\
\end{array}$ & $\begin{array}{c}0.06 \\
(0.01) \\
\end{array}$ & 0.0022 & $\begin{array}{c}0.09 \\
(0.02) \\
\end{array}$ & $\begin{array}{c}0.04 \\
(0.01)\end{array}$ & 0.0119 & $\begin{array}{c}0.07 \\
(0.01) \\
\end{array}$ & $\begin{array}{c}0.04 \\
(0.01) \\
\end{array}$ & 0.0500 \\
\hline Spain & $\begin{array}{c}0.15 \\
(0.02) \\
\end{array}$ & $\begin{array}{c}0.11 \\
(0.02) \\
\end{array}$ & 0.0905 & $\begin{array}{c}0.10 \\
(0.02) \\
\end{array}$ & $\begin{array}{c}0.04 \\
(0.01) \\
\end{array}$ & 0.0011 & $\begin{array}{c}0.13 \\
(0.02) \\
\end{array}$ & $\begin{array}{c}0.14 \\
(0.02) \\
\end{array}$ & 0.4955 \\
\hline Sweden & $\begin{array}{c}0.15 \\
(0.02) \\
\end{array}$ & $\begin{array}{c}0.05 \\
(0.01) \\
\end{array}$ & 0.0000 & $\begin{array}{c}0.09 \\
(0.01) \\
\end{array}$ & $\begin{array}{c}0.02 \\
(0.01) \\
\end{array}$ & 0.0000 & $\begin{array}{c}0.08 \\
(0.02) \\
\end{array}$ & $\begin{array}{c}0.04 \\
(0.01) \\
\end{array}$ & 0.0092 \\
\hline Switzerland & $\begin{array}{c}0.07 \\
(0.01) \\
\end{array}$ & $\begin{array}{c}0.04 \\
(0.01) \\
\end{array}$ & 0.0336 & $\begin{array}{c}0.05 \\
(0.01) \\
\end{array}$ & $\begin{array}{c}0.04 \\
(0.01) \\
\end{array}$ & 0.3262 & $\begin{array}{c}0.06 \\
(0.01) \\
\end{array}$ & $\begin{array}{c}0.06 \\
(0.01) \\
\end{array}$ & 0.7995 \\
\hline Turkey & $\begin{array}{c}0.34 \\
(0.02) \\
\end{array}$ & $\begin{array}{c}0.19 \\
(0.03) \\
\end{array}$ & 0.0003 & $\begin{array}{c}0.12 \\
(0.02) \\
\end{array}$ & $\begin{array}{c}0.07 \\
(0.02) \\
\end{array}$ & 0.0528 & $\begin{array}{c}0.39 \\
(0.02) \\
\end{array}$ & $\begin{array}{c}0.23 \\
(0.03) \\
\end{array}$ & 0.0001 \\
\hline Ukraine & $\begin{array}{c}0.14 \\
(0.02)\end{array}$ & $\begin{array}{c}0.07 \\
(0.01)\end{array}$ & 0.0008 & $\begin{array}{c}0.05 \\
(0.01)\end{array}$ & $\begin{array}{c}0.03 \\
(0.01)\end{array}$ & 0.0675 & $\begin{array}{c}0.12 \\
(0.02)\end{array}$ & $\begin{array}{c}0.08 \\
(0.01)\end{array}$ & 0.0336 \\
\hline
\end{tabular}




\section{Pooled data estimations}

The results of estimating (1) with the data that pools together men and women are displayed in Table 4A. ${ }^{25}$ To save space, we only report the estimates for the variable gender. All the regressions control for the same covariates we use in the regressions that are split between men and women (Section 6). ${ }^{26}$

In the full sample (second row) the estimates show that women are 5.2 percentage points less likely to be an entrepreneur compared to men. This is substantially lower than the 7 percentage point difference we observed in the raw data (Table 2), indicating that part of this gap can be explained with our controls. The magnitude of this gap varies by the type of entrepreneurial activity, with the difference being larger in the case of employers (4 percentage points) than in the case of self-employed ( 2 percentage points). The gender gap in employers is similar than that of the raw data whereas the gap in self-employed is smaller. This gender effect is large in magnitude and always significant at the $1 \%$ confidence level. The existing literature finds that women tend to operate smaller sized business establishments and, consistent with this, we find that the gender gap is lowest in magnitude for self-employment. However our regressions- and most of the literature- is unable to clarify whether women chose to engage in small-scale businesses or if they do so as a response to the constraints they may face.

In the sample of Ex-Communist countries (third row) women are 5.3\% less likely to be entrepreneurs. The gap again varies by type of entrepreneurial activity with women $4 \%$ and $1.7 \%$ less likely to be an employer and self-employed respectively. These are similar in magnitude to the full sample of countries.

In the sample of lower income countries (fourth row) only the gender gap in entrepreneurship is statistically significant but not the gender gap by types of entrepreneurial activities. The magnitude of the gap at 3.9\% is comparatively lower than the full sample of countries. While family background and partner being an entrepreneur continue to be key determinants of entrepreneurship, other factors that have a statistically significant effect are education levels, trust in people, membership in professional association and unemployment.

\footnotetext{
${ }^{25}$ We report only the marginal effects associated with the estimated coefficients of the probit model.

${ }^{26}$ The coefficients associated with each of the other regressors are available from the authors upon request.
} 
Table 4A: Marginal effects of gender on entrepreneurship in the pooled sample

\begin{tabular}{cccc}
\hline & Entrepreneurs & Employers & Self-Employed \\
\hline Full sample & $-0.0518^{* * *}$ & $-0.0402^{* * *}$ & $-0.0213^{* * *}$ \\
& $(0.00975)$ & $(0.00659)$ & $(0.00810)$ \\
\hline Ex-communist & $-0.0526^{* * *}$ & $-0.0401^{* * *}$ & $-0.0174^{* *}$ \\
countries & $(0.00965)$ & $(0.00829)$ & $(0.00751)$ \\
\hline Lower income & $-0.0392^{* *}$ & -0.0226 & -0.0201 \\
countries & $(0.0194)$ & $(0.0171)$ & $(0.0168)$ \\
\hline
\end{tabular}




\section{Evolution of gender gaps by country}
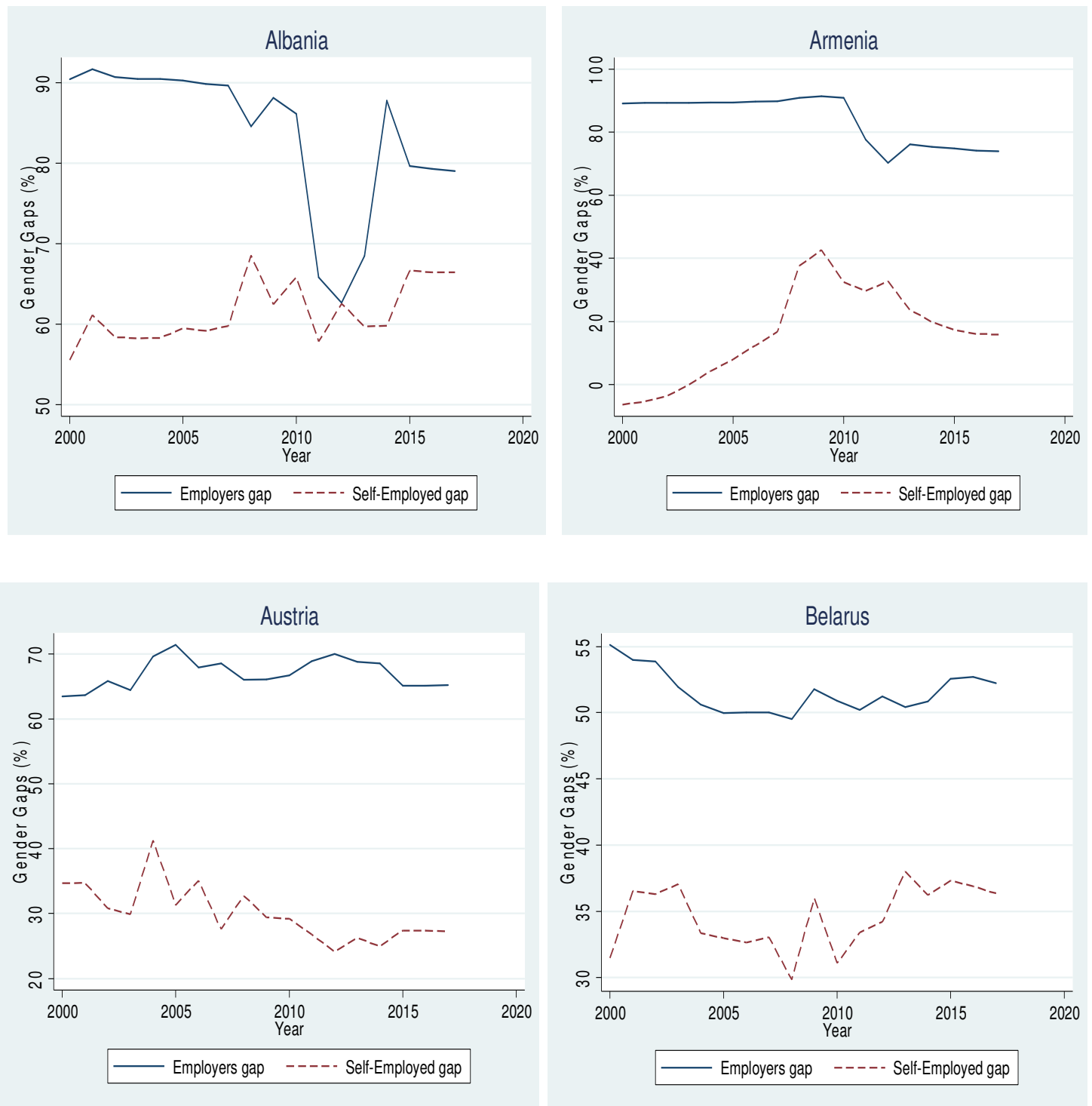

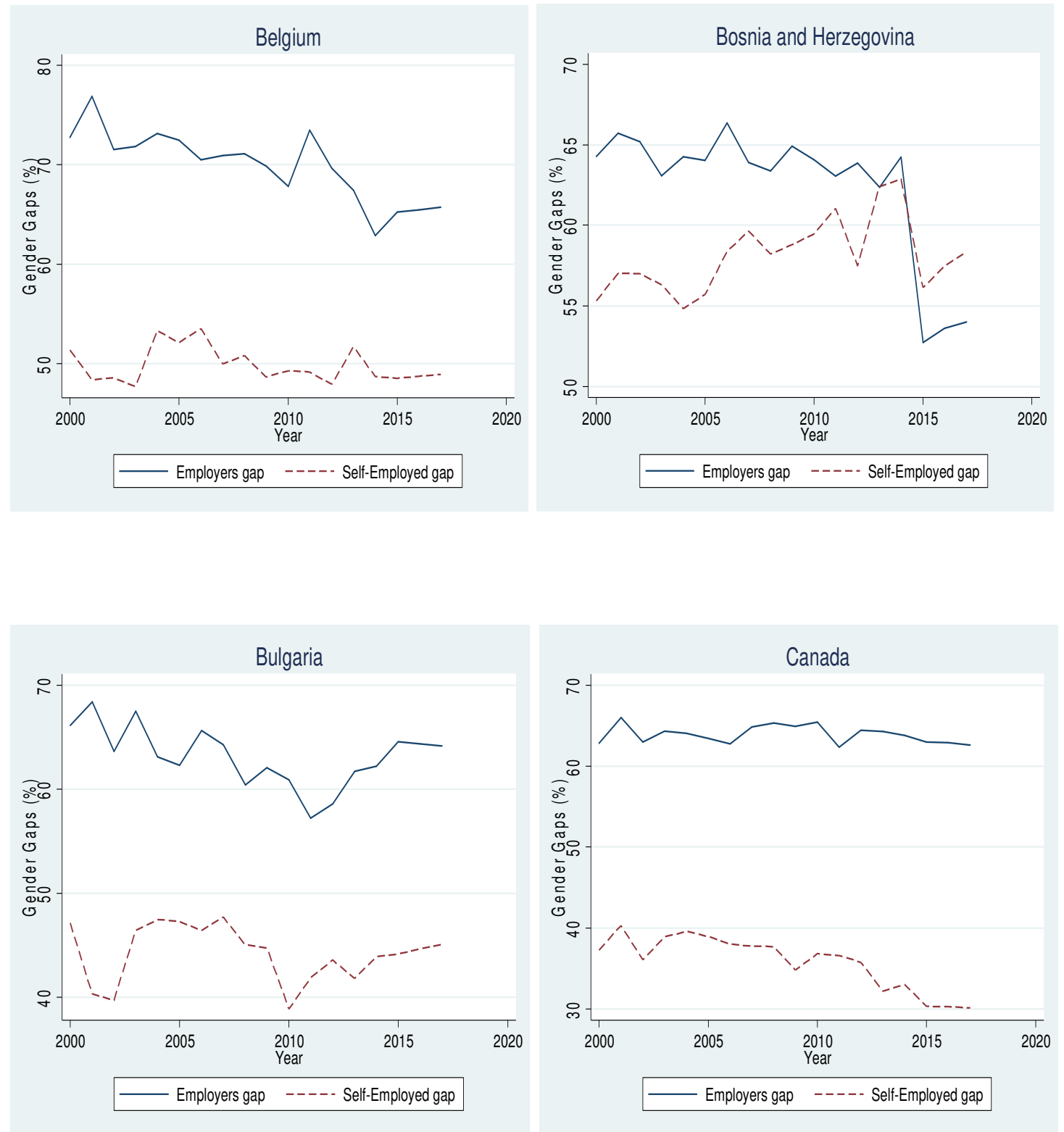

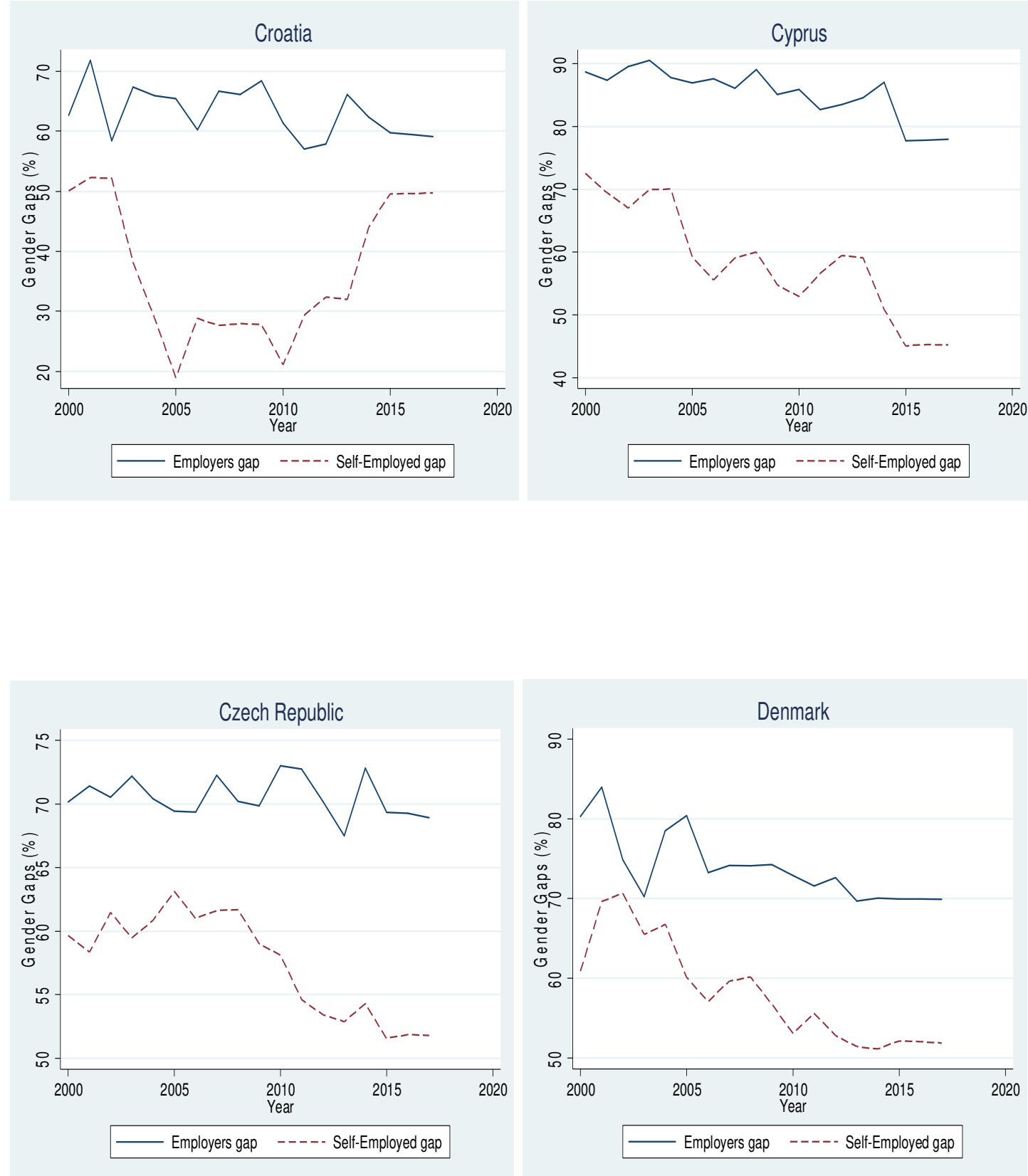

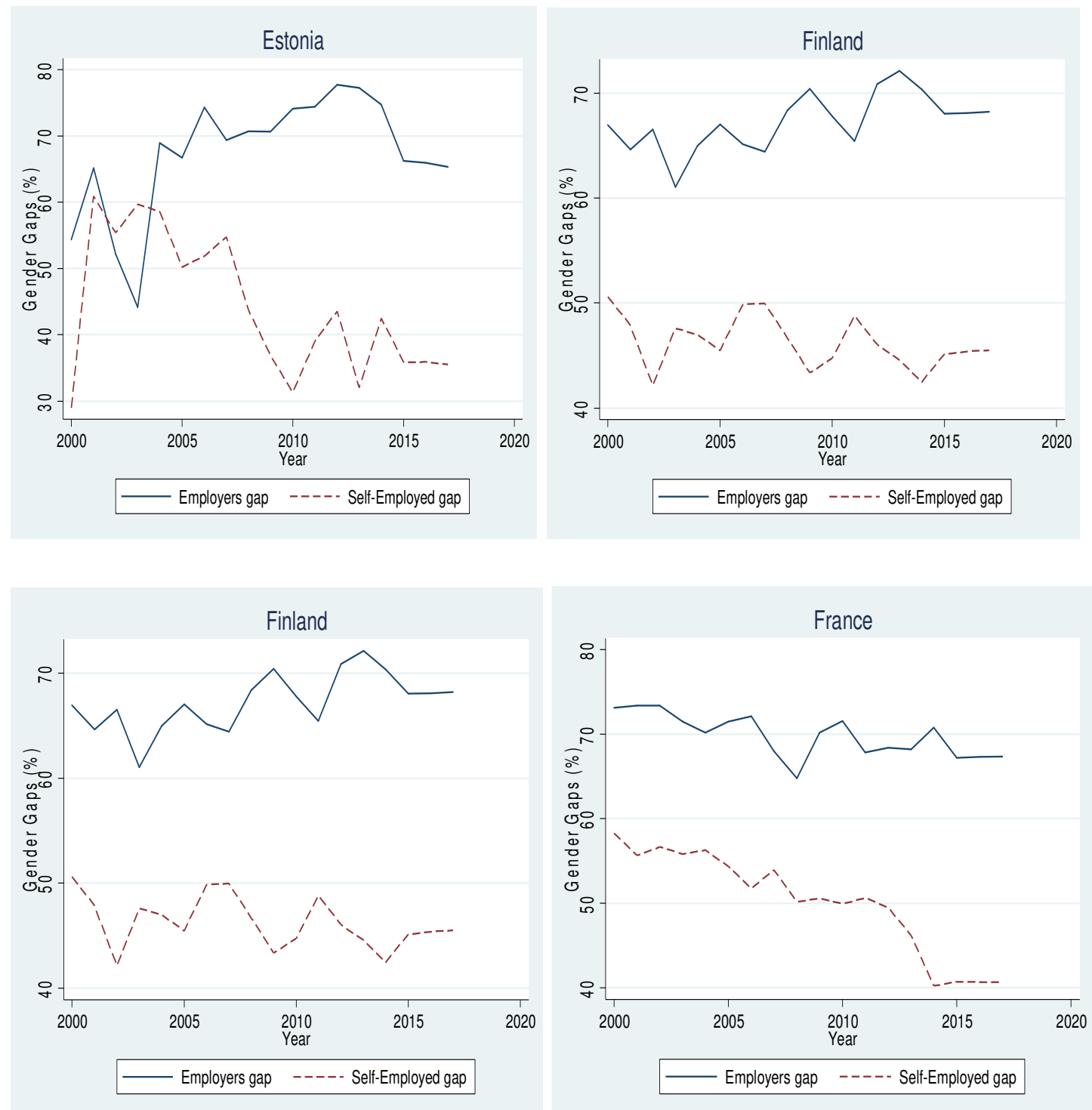

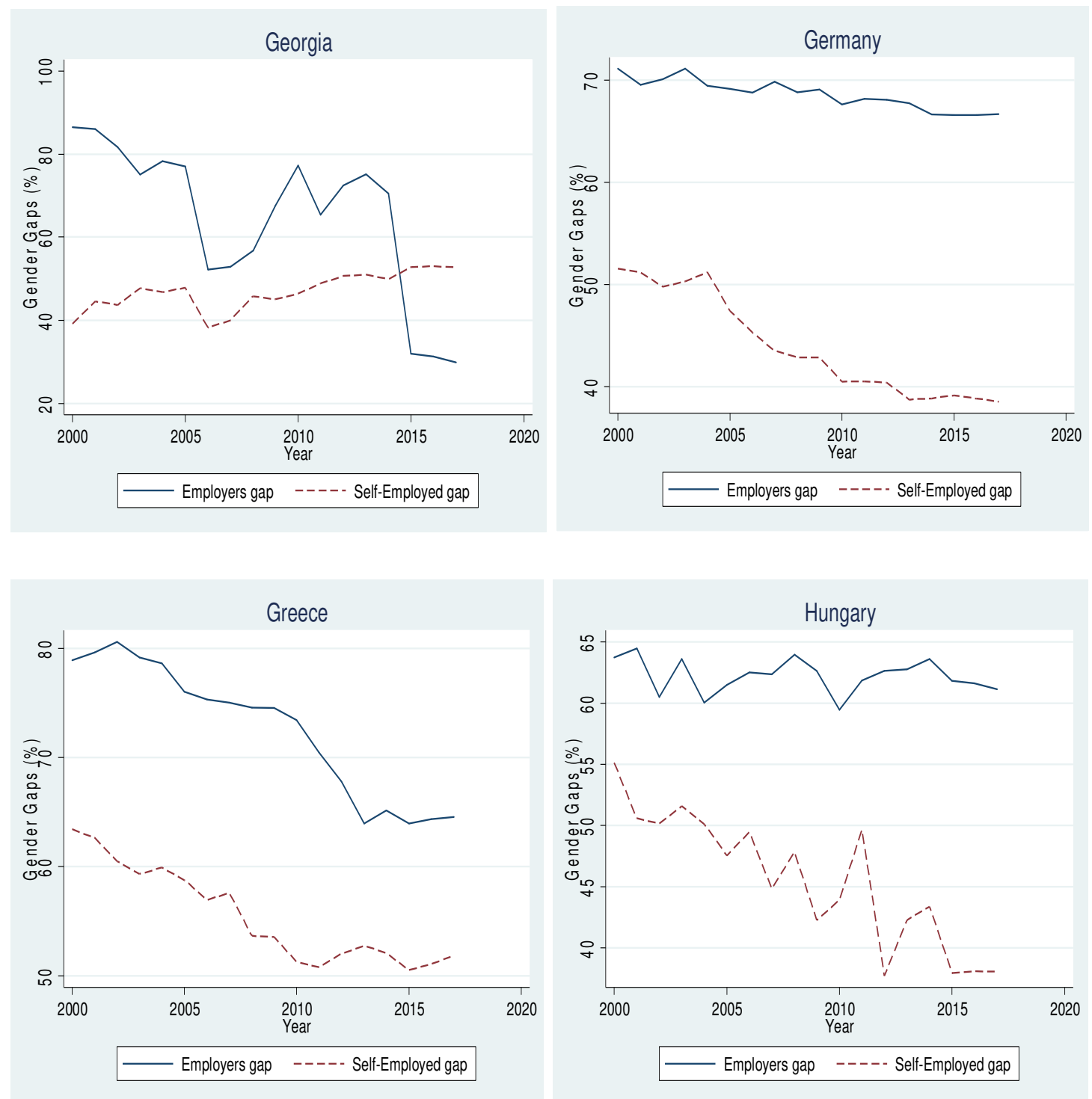

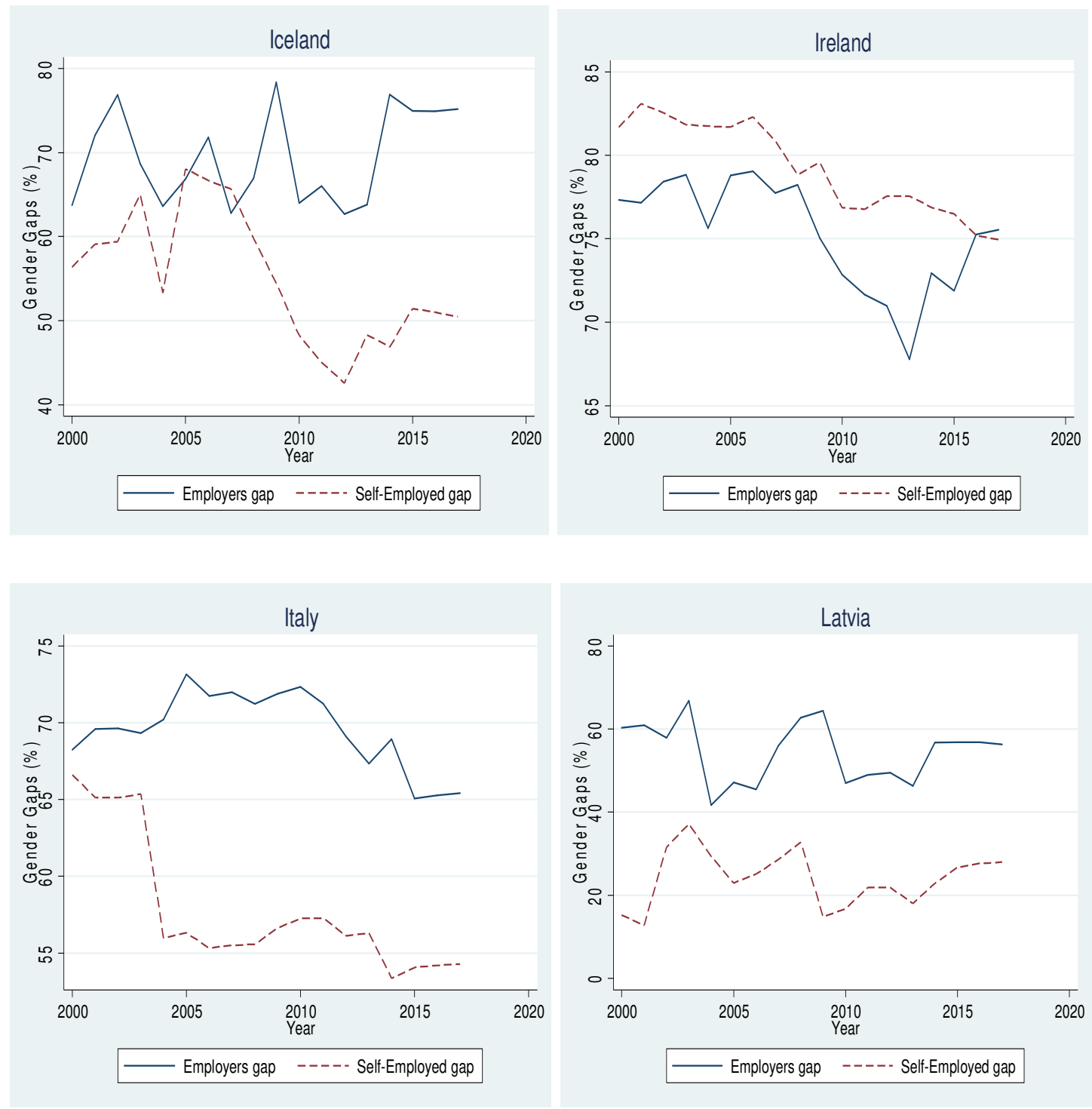

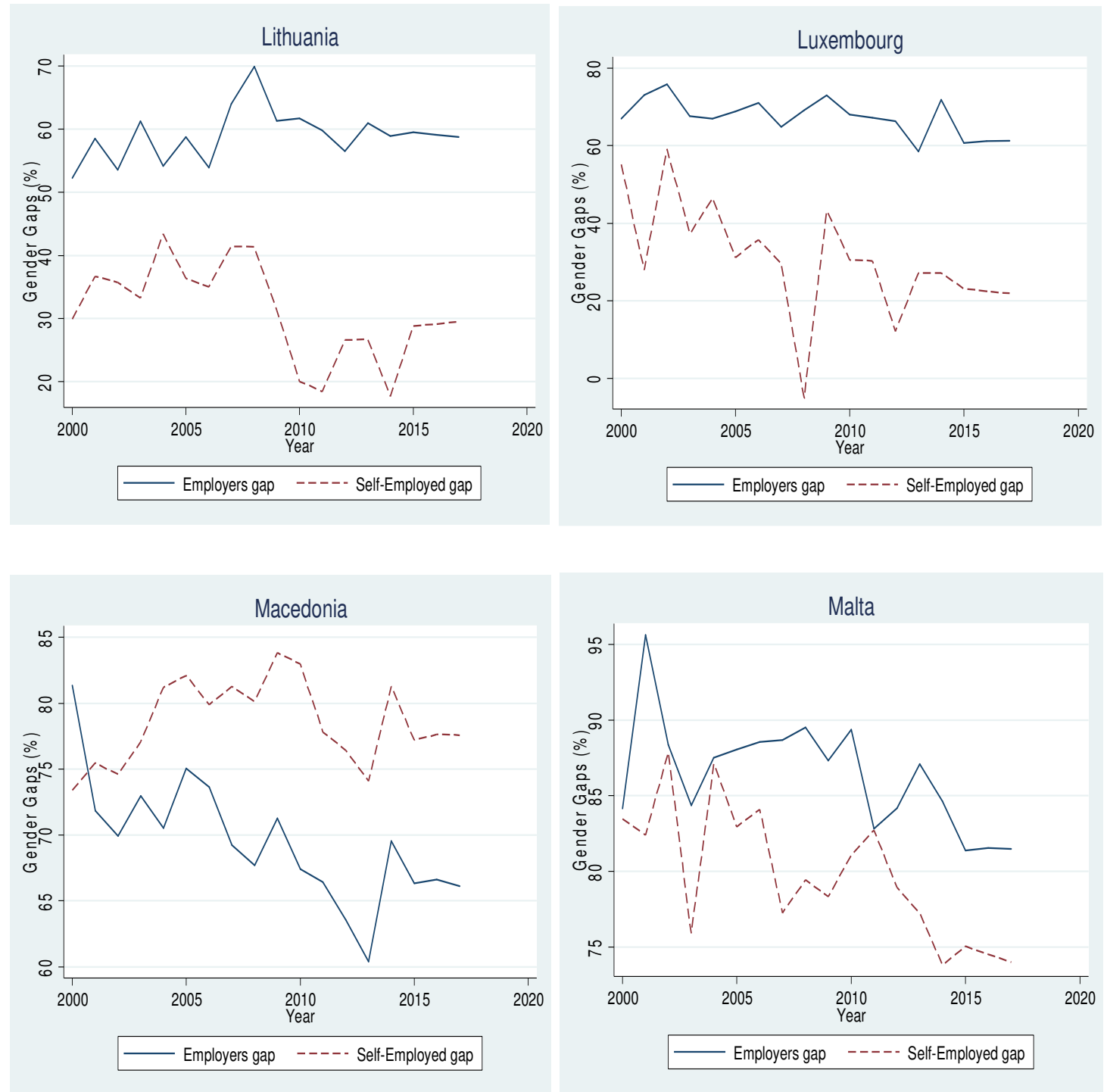

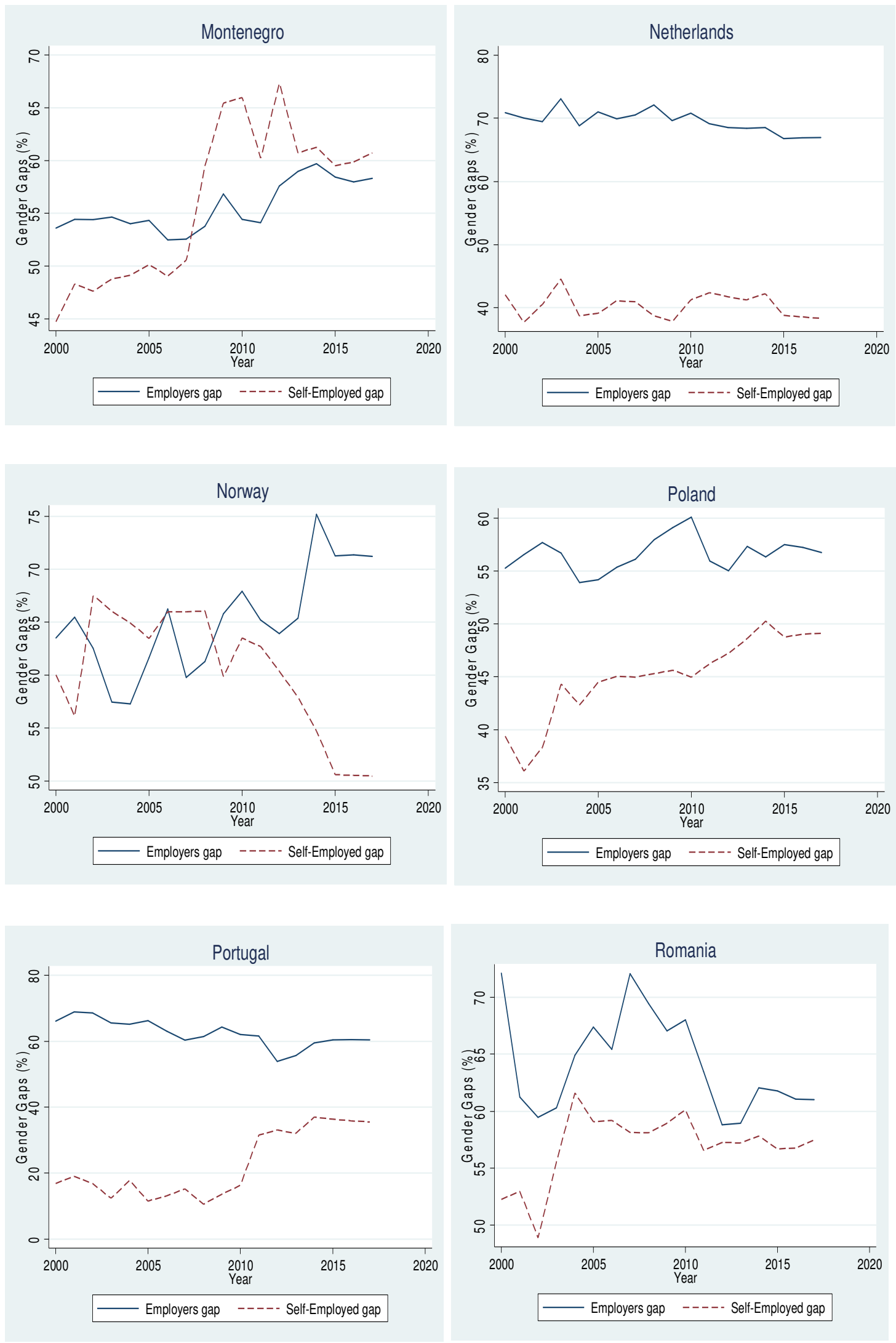

34 

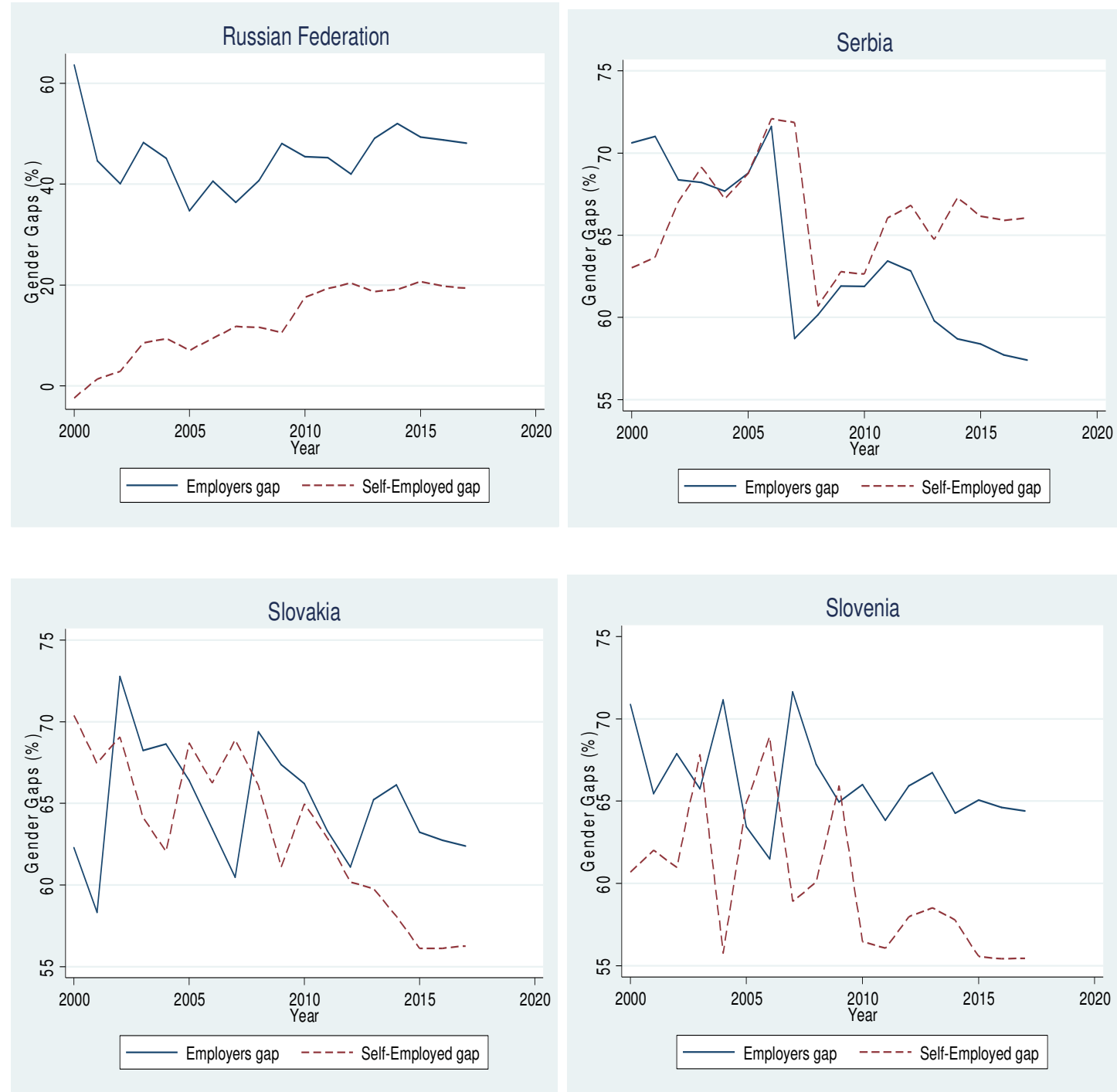

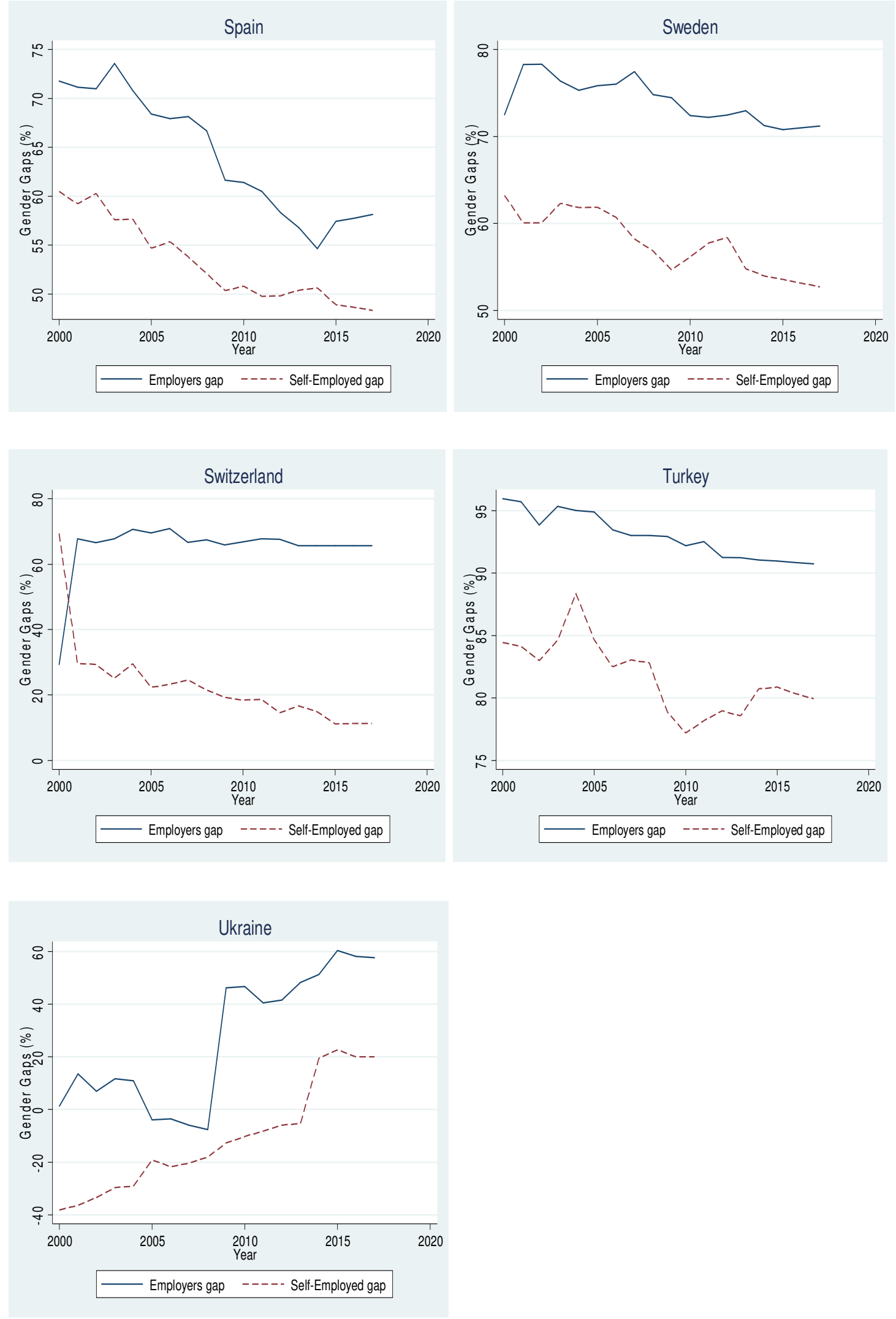


\section{References}

Alene, A.D, V.M. Manyong, G.O. Omanya, H.D. Mignouna, M. Bokanga, and G.D. Odhiambo. 2008. Economic Efficiency and Supply Response of Women as Farm Managers: Comparative Evidence from Western Kenya. World Development 36(7): 1247-1260.

Becker, G.S., and H.G. Lewis. 1973. On the Interaction between the Quantity and Quality of Children. Journal of Political Economy 81: S279-S88.

Becker, G. S. 1985. Human capital, effort, and the sexual division of labor. Journal of labor economics, 3(1, Part 2), S33-S58.

Bernhardt, I. 1994. Comparative advantage in self-employment and paid work. Canadian Journal of Economics, 27, 273 \pm 289.

Berniell, M.I, and C. Sánchez-Páramo. 2011. Overview of Time Use Data Used for the Analysis of Gender Differences in Time Use Patterns. Background paper for the WDR 2012.

Bertrand, M M. 2011. New perspectives on gender. Handbook of labor economics, 4, 1543-1590.

Black, S. E., and P. E. Strahan. 2002. Entrepreneurship and bank credit availability. The Journal of Finance, vol. 57, issue 6, 2807-2833.

Blanchflower, D. G. 2000. Self-employment in OECD countries. Labour economics 7 , 471-505.

Blanchflower, D. G., and A. J. Oswald. 1998. What makes an entrepreneur? Journal of Labor Economics, vol 16, No 1.

Cagetti, M., and De Nardi, M. 2006. Entrepreneurship, frictions, and wealth. Journal of Political Economy, 114, 5, October.

Carrasco, R. 1999, Transitions to and from self-employment in Spain: an empirical analysis. Oxford Bulletin of Economics and Statistics. Volume 61, Issue 3 August, 315-341.

Croson, D. C., and Minniti, M. 2012. Slipping the surly bonds: The value of autonomy in self-employment. Journal of Economic Psychology, 33(2), 355-365.

Cuberes, D., and Teignier, M. 2012., Gender inequality and economic growth., background paper for the 2012 World Development Report, in Chapter 5 "Gender differences in employment and why they matter. The World Bank. 
Cuberes, D., and Teignier, M. 2014., Gender inequality and economic growth: A critical review. Journal of International Development, vol. 26, Issue 2, pp. 260276, March.

Cuberes, D., and Teignier, M. 2016., Aggregate effects of gender gaps in the labor market: A quantitative estimate., Journal of Human Capital, volume 10, 1, Spring.

Dollar, D., and Gatti, R. 1999. Gender inequality, income and growth: Are good times good for women? Policy Research Report on Gender and Development Working Paper Series No. 1. World Bank, Washington, DC.

Dunn, T., and Holtz-Eakin, D. 2000. Financial capital, human capital, and the transition to self-employment: Evidence from intergenerational links. Journal of labor economics, 18(2), 282-305.

Eren, O., and Sula, O. 2012. The effect of ability on young men's self-employment decision: evidence from the NELS. Industrial Relations: A Journal of Economy and Society, 51(4), 916-935.

Evans, D. S., and Jovanovic, B. 1989. An estimated model of entrepreneurial choice under liquidity constraints. Journal of Political Economy, 97(4), 808-827.

Evans, D. S., and Leighton, L. S. 1989. Some empirical aspects of entrepreneurship. American Economic Review, 79(3), 519-535.

Fairlie, R. W., and Meyer, B. D. 1996. Ethnic and racial self-employment differences and possible explanations. Journal of Human Resources, Vol. 31, No. 4. Autumn, pp. 757-793.

Fernandez, R. 2013. Cultural change as learning: The evolution of female labor force participation over a century." American Economic Review, forthcoming.

Fortin, N. M., 2005. Gender role attitudes and the labour-market outcomes of women across OECD countries. Oxford Review of Economic Policy 21 (3): 416-38.

Hurst, E., and Lusardi, A. 2004. Liquidity constraints, household wealth, and entrepreneurship. Journal of Political Economy, 112(2), 319-347.

International Monetary Fund, 2017. Gender inequality and macroeconomic erformance. Chapter 3 in Women, Work, and Economic Growth. Leveling the Playing Field. Edited by Kalpana Kochhar, Sonali Jain-Chandra, and Monique Newiak. International Monetary Fund.

Knack, S., and Keefer, P. 1997. Does social capital have an economic payoff? A crosscountry investigation. The Quarterly journal of economics, 112(4), 1251-1288. 
Kodila-Tedika, O., and Agbor, J. 2016. Does Trust Matter for Entrepreneurship: Evidence from a Cross-Section of Countries. Economies, 4(1), 4.

Le, A.T. 1999. Empirical studies of self-employment Journal of Economic Surveys, vol 13, No 4.

Lindquist, M. J., Sol, J., \& Van Praag, M. 2015. Why do entrepreneurial parents have entrepreneurial children? Journal of Labor Economics, 33(2), 269-296.

Özcan, B., 2011. Only the lonely? The influence of the spouse on the transition to selfemployment. Small Business Economics, 37(4), 465.

Poschke, M., 2013. Entrepreneurs out of necessity': A snapshot.” Applied Economics Letters 20 (7): 658-63.

Putnam, R., 1993. Making democracy work. Civic traditions in modern Italy. Princeton, NJ: Princeton University Press.

Rees and Shah 1986

Ruef, M., H. E. Aldrich, and N.C. Carter, 2003. The structure of founding teams: homophily, strong ties, and isolation among U.S. entrepreneurs, American Sociological Review, Vol. 68:195-222

Skriabikova, O. J., Dohmen, T., \& Kriechel, B., 2014. New evidence on the relationship between risk attitudes and self-employment. Labour Economics, 30, 176-184.

Stotsky, J. G., 2006. Gender and its relevance to macroeconomic policy: A survey. IMF Working Paper WP/06/233.

Taylor, M. P., 1996. Earnings, independence or unemployment: why become selfemployed? Oxford Bulletin of Economics and Statistics. Vol 58, Issue 2, May. 253266

Tzannatos, Z., 1999. Women and labor market changes in the global economy: Growth helps, inequalities hurt and public policy matters. World Development 27(3): 551569.

D Ucbasaran, Westhead, P., and M Wright, M., 2008. Opportunity identification and pursuit: Does an entrepreneur's human capital matter? Small Business Economics.

Unger, J. M. Rauch, A., Frese, M., and Rosenbusch, N. 2011. Human capital and entrepreneurial success: A meta-analytical review - Journal of Business. 
Wellington, A. J., 2006. Self-employment: the new solution for balancing family and career? Labour Economics, 13(3), 357-386.

World Bank. 2013. Gender at Work: A Companion to the World Development Report on Jobs. Washington, World Bank.

World Development Report, 2012. Gender Equality and Development. The World Bank. Washington, DC. 